OPEN ACCESS

Edited by:

Maria Snoussi,

Mohammed V University, Morocco

Reviewed by:

Edward Hanna,

University of Lincoln, United Kingdom Horst Machguth,

Université de Fribourg, Switzerland

Andrew John Sole,

The University of Sheffield,

United Kingdom

*Correspondence:

Fiammetta Straneo

fstraneo@ucsd.edu

Specialty section: This article was submitted to

Ocean Observation,

a section of the journal

Frontiers in Marine Science

Received: 14 November 2018

Accepted: 05 March 2019

Published: 29 March 2019

Citation:

Straneo $F$, Sutherland $D A$, Stearns L, Catania G, Heimbach P, Moon T, Cape MR, Laidre KL, Barber D, Rysgaard S, Mottram R, Olsen S, Hopwood MJ and Meire L

(2019) The Case for a Sustained

Greenland Ice Sheet-Ocean

Observing System (GrlOOS).

Front. Mar. Sci. 6:138.

doi: 10.3389/fmars.2019.00138

\section{The Case for a Sustained Greenland Ice Sheet-Ocean Observing System (GrIOOS)}

\author{
Fiammetta Straneo ${ }^{*}$, David A. Sutherland ${ }^{2}$, Leigh Stearns ${ }^{3}$, Ginny Catania ${ }^{4}$, \\ Patrick Heimbach ${ }^{4}$, Twila Moon ${ }^{5}$, Mattias R. Cape ${ }^{6}$, Kristin L. Laidre ${ }^{7}$, Dave Barber ${ }^{8}$, \\ Søren Rysgaard ${ }^{8,9,10}$, Ruth Mottram ${ }^{11}$, Steffen Olsen ${ }^{11}$, Mark J. Hopwood ${ }^{12}$ and \\ Lorenz Meire ${ }^{10,13}$
}

\begin{abstract}
${ }^{1}$ Scripps Institution of Oceanography, University of California, San Diego, La Jolla, CA, United States, ${ }^{2}$ Department of Earth Sciences, University of Oregon, Eugene, OR, United States, ${ }^{3}$ Department of Geology, University of Kansas, Lawrence, KS, United States, ${ }^{4}$ Oden Institute for Computational Engineering and Sciences and Jackson School of Geosciences, University of Texas at Austin, Austin, TX, United States, ${ }^{5}$ National Snow and Ice Data Center, Cooperative Institute for Research in Environmental Sciences, University of Colorado, Boulder, Boulder, CO, United States, ${ }^{6}$ School of Oceanography, University of Washington, Seattle, WA, United States, ${ }^{7}$ Polar Science Center, Applied Physics Laboratory, University of Washington, Seattle, WA, United States, ${ }^{8}$ Centre for Earth Observation Science, Department of Environment and Geography, University of Manitoba, Winnipeg, MB, Canada, ${ }^{9}$ Arctic Research Centre, Aarhus University, Aarhus, Denmark, ${ }^{10}$ Greenland Climate Research Centre, Greenland Institute of Natural Resources, Nuuk, Greenland, ${ }^{11}$ Danish Meteorological Institute, Copenhagen, Denmark, ${ }^{12}$ GEOMAR Helmholtz Centre for Ocean Research Kiel, Kiel, Germany,

${ }^{13} \mathrm{NIOZ}$ Royal Netherlands Institute of Sea Research and Utrecht University, Yerseke, Netherlands
\end{abstract}

Rapid mass loss from the Greenland Ice Sheet (GrlS) is affecting sea level and, through increased freshwater and sediment discharge, ocean circulation, sea-ice, biogeochemistry, and marine ecosystems around Greenland. Key to interpreting ongoing and projecting future ice loss, and its impact on the ocean, is understanding exchanges of heat, freshwater, and nutrients that occur at the GrIS marine margins. Processes governing these exchanges are not well understood because of limited observations from the regions where glaciers terminate into the ocean and the challenge of modeling the spatial and temporal scales involved. Thus, notwithstanding their importance, ice sheet/ocean exchanges are poorly represented or not accounted for in models used for projection studies. Widespread community consensus maintains that concurrent and long-term records of glaciological, oceanic, and atmospheric parameters at the ice sheet/ocean margins are key to addressing this knowledge gap by informing understanding, and constraining and validating models. Through a series of workshops and documents endorsed by the community-at-large, a framework for an international, collaborative, Greenland Ice sheet-Ocean Observing System (GrlOOS), that addresses the needs of society in relation to a changing GrIS, has been proposed. This system would consist of a set of ocean, glacier, and atmosphere essential variables to be collected at a number of diverse sites around Greenland for a minimum of two decades. Internationally agreed upon data protocols and data sharing policies would guarantee uniformity and availability of the information for the broader community. Its 
development, maintenance, and funding will require close international collaboration. Engagement of end-users, local people, and groups already active in these areas, as well as synergy with ongoing, related, or complementary networks will be key to its success and effectiveness.

Keywords: Greenland, ice sheet, ocean, observing system, glacier, atmosphere

\section{INTRODUCTION}

\section{Scientific Rationale for a Greenland Ice Sheet-Ocean Observing System}

Rapid mass loss from the Greenland Ice Sheet (GrIS) has raised interest in glacier-ocean interactions for three main reasons. First, melting at the marine margins of Greenland glaciers has emerged as a potential trigger of the observed dynamic ice loss (roughly half of the total ice loss) with important consequences for sea level rise. Second, increased freshwater discharge from the GrIS has the potential to impact global climate by affecting the Atlantic Meridional Overturning Circulation. Third, by altering nutrient fluxes, productivity, and biogeochemical properties of coastal waters, changes in freshwater discharge may impact marine ecosystems along the Greenland margin and potentially farther afield in the North Atlantic, with consequences for organisms using these regions as habitat and feeding grounds as well as societies relying on these ecosystems for subsistence.

Notwithstanding their importance, the exchanges of heat, freshwater, and nutrients that occur at the GrIS's marine margins are poorly understood and largely not accounted for in earth systems models used for projection studies that are part of the Climate Model Intercomparison Project and the Ice Sheet Modeling Intercomparison Project in support of the Intergovernmental Panel on Climate Change. This is largely due to the fact that exchanges between the GrIS and the surrounding ocean occur at the head of long, narrow, glacial fjords, at spatial scales inaccessible to earth systems models for the foreseeable future. Processes occurring at the ice sheet-ocean boundary include iceberg calving, sediment-laden turbulent upwelling plumes from surface meltwater discharge at depth (subglacial discharge), glacier submarine melting, fjord circulation, and strong katabatic winds. All of these processes are intrinsically challenging to observe and quantify because of their complexity and small spatial scales. On the glacier side, changes at the ice sheet-ocean boundary can trigger a dynamic response (i.e., stress perturbations in the ice sheet momentum balance) that results in thinning of the upstream glacier and further ice loss.

Considerable progress has been made over the last decade in understanding ice sheet-ocean exchanges of heat and freshwater in Greenland's glacial fjords. Yet challenges remain to understand the climatic controls on submarine melting, iceberg calving, the delivery of meltwater to the large-scale ocean, changes in nutrient availability, and the response of marine ecosystems. These knowledge gaps translate into an inability to appropriately represent these processes, even in parameterized form, in ice sheet, ocean, and climate models aimed at projection. Above all, there is widespread community consensus that progress requires concurrent and long-term records of glaciological, oceanic, and atmospheric parameters at the ice sheet-ocean margins - where the exchanges of heat, nutrients, and freshwater are occurring. Such observations are key to informing understanding, and constraining and validating models.

Tremendous efforts over the last decade have been devoted to pioneering measurements in glacial fjords and at glacier margins - challenging-to-access locations where no previous measurements existed and conventional observing techniques cannot be applied. These new measurements, and the model studies stimulated by them, have led to considerable advances in understanding ice sheet-ocean exchanges (Vieli and Nick, 2011; Straneo and Cenedese, 2015; Mortensen et al., 2018). These efforts, however, were not aimed at observing the entire system, including potential feedbacks and non-linearities, over extended periods of time. Here, following a series of workshops and documents endorsed by the community-at-large, we articulate the framework for an international, collaborative Greenland Ice sheet-Ocean Observing System (GrIOOS) that addresses the needs for society in the context of a changing GrIS.

\section{Motivation}

Rapidly increasing ice loss from the GrIS (Hanna et al., 2013; Velicogna et al., 2014; Bamber et al., 2018) has raised interest in the exchange of heat, freshwater, and nutrients between the GrIS and the subpolar North Atlantic, the Arctic, the Nordic Seas, and Baffin Bay, and their impact on marine ecosystems, for multiple reasons.

\section{Sea Level Rise}

Through rapid and sustained ice loss, the GrIS accounts for $25 \%$ of present day sea level rise, roughly twice that from Antarctica (Chambers et al., 2017; Dieng et al., 2017; WCRP Global Sea Level Budget Group, 2018). Ice loss occurs through changes in surface mass balance (ultimately inputting liquid freshwater to the ocean via surface and subglacial meltwater discharge) and in calving (inputting solid freshwater to the ocean). Changes in calving, in turn, can occur in response to oceanic and atmospheric variability (Holland et al., 2008; Hanna et al., 2009; Motyka et al., 2011; Straneo et al., 2013; Straneo and Heimbach, 2013). Recent increases in GrIS mass loss are primarily due to variations in surface mass balance, though solid ice discharge contributions have made up between $\sim 30 \%$ and $\sim 60 \%$ of total mass losses within recent decades (Enderlin et al., 2014; Van den Broeke et al., 2016). Increased iceberg calving and submarine melting have been identified as potential triggers for increased ice discharge (Motyka et al., 2011; Catania et al., 2018). Quantifying processes occurring at the ice-ocean interface thus becomes a 
high priority activity and prerequisite for projecting sea level rise from the GrIS.

\section{Increased Freshwater Discharge Into the North Atlantic}

A direct consequence of ice loss from the GrIS is the increase in the liquid (meltwater) and solid (iceberg) discharge of freshwater into the North Atlantic (Rignot et al., 2008; Bamber et al., 2012, 2018; Enderlin et al., 2016). This has raised concerns for the impact on the meridional overturning circulation, with potentially important climate consequences for society, based on past reconstructions and model projections (Böning et al., 2016; Yang et al., 2016; Thornalley et al., 2018). Our ability to project the impact of a shrinking GrIS on the large scale ocean circulation, however, is strongly dependent on the formulation of appropriate GrIS freshwater discharge boundary conditions in coupled ocean-atmosphere or ocean-only models. At present, the most up-to-date boundary conditions quantify the ice and meltwater discharge at the ice sheet-ocean margins, typically at the head of the narrow fjords, but neglect transformations within the fjords (Bamber et al., 2012, 2018). In contrast, observations and model studies of Greenland's fjords reveal a substantial modification of the freshwater discharge by in-fjord processes including iceberg melt, dilution of surface melt by turbulent plumes and, in general, a more complex fjord-ocean exchange of freshwater than that of a surface, freshwater export (Beaird et al., 2015, 2018; Enderlin et al., 2016; Jackson and Straneo, 2016; Moon et al., 2017; Mortensen et al., 2018). Understanding and appropriately formulating boundary conditions regarding freshwater flux is thus a key step in projecting the impact of the GrIS mass loss on the ocean.

\section{Impact on Ocean Biogeochemistry and Marine Ecosystems}

Interactions between the ocean and ice sheet fundamentally impact the biogeochemistry and structure of marine ecosystems in glacial fjords along the coast of Greenland. High rates of summertime primary productivity and phytoplankton biomass, coincident with nutrient enrichment of the upper water column downstream of marine-terminating glaciers, have been attributed to the sustained upwelling of deep, nutrient-rich ocean waters entrained as a result of subglacial discharge (Meire et al., 2017; Overeem et al., 2017; Hopwood et al., 2018; Kanna et al., 2018; Cape et al., 2019). This upwelling of nutrients is also thought to contribute to a lengthening of the growth season within glacial fjords, with secondary summer blooms accounting for an unusually large fraction of annual primary production (Juul-Pedersen et al., 2015). In contrast, no fjord-scale, positive fertilization effect is generally observed downstream of landterminating glaciers, where glacial meltwater exported into surface waters primarily contributes to the strengthening of the pycnocline, exacerbating nutrient limitation (Meire et al., 2017). In addition to the carbon sink arising from high productivity in some fjords, the mixing of glacial melt with ambient ocean waters results in fjord waters that are significantly undersaturated in $\mathrm{CO}_{2}$, suggesting that glacially influenced coastal waters constitute important $\mathrm{CO}_{2}$ sinks along the Greenland margins (Rysgaard et al., 2012; Fransson et al., 2015; Meire et al., 2015). The correlation between the distribution of meltwater and timing of phytoplankton blooms on parts of the Greenland continental shelf further suggests that meltwater arrival may also be a factor in summertime bloom initiation beyond the confines of glacierfjord systems (Arrigo et al., 2017; Oliver et al., 2018). However, large-scale impacts of freshwater export from the GrIS as a result of the potential export of glacially derived iron to iron-limited regions of the North Atlantic, remain poorly constrained owing to a limited understanding of the fate of glacially modified waters and their nutrients beyond the confines of Greenland's fjords.

Like other Arctic and sub-Arctic glacial systems, Greenland glacial fjords are hotspots of secondary productivity, characterized by rich marine ecosystems featuring high densities of seabirds, marine mammals, and fishes (Lydersen et al., 2014; O’Neel et al., 2015; Laidre et al., 2016; Meire et al., 2017). They serve as important sites for traditional hunting, subsistence, and commercial fisheries (Meire et al., 2017), contributing significantly to the regional economy (Berthelsen, 2014). In addition to sustaining high productivity, processes occurring at the ice sheet-ocean interface may aggregate plankton or stun plankton via freshwater osmotic shock (Lydersen et al., 2014), making them easy prey for larger surface-feeding predators and multiple trophic levels. In general, the glacier ice mélange, a heterogeneous mixture of calved glacial ice and sea ice that can freeze solid, is a primary habitat for Arctic marine mammals in glacial fjords. In winter and spring, this solid area produces a heterogeneous habitat for ringed seals (Pusa hispida), bearded seals (Erignathus barbatus), polar bears (Ursus maritimus), numerous sea birds, and land mammals such as Arctic fox (Vulpes lagopus) (Laidre et al., 2018a,b). Other species that are ice-associated, such as the narwhal (Monodon monoceros), forage at the glacier front and among the mélange to utilize the productive waters during summer (Laidre et al., 2016). In some areas of the Arctic where the permanent multi-year sea ice has vanished in recent years, glacial fjords are replacing sea ice habitat for ice-breeding species that require stable ice for reproduction (Lydersen et al., 2014).

Ongoing changes at the ice sheet-ocean margins, including increasing freshwater discharge into coastal fjords, have led to questions regarding how these changes will impact carbon cycling, whether changes in the physical habitat may impact populations that rely on glacial fjords for habitat, refuge, and subsistence, and what the consequences will be for the patterns and timing of biological productivity - which may have cascading effects up the food chain. Thus, understanding the influence of ice loss on biological systems, including fisheries, is a major thrust of Greenland ice sheet-ocean exchange research.

\section{Outlet Glaciers and Glacial Fjords}

Unraveling the variability of processes occurring at outlet glacier marine margins and in glacial fjords is essential to make progress on the overarching questions pertaining to drivers of mass loss from the GrIS and their impact on the ocean circulation, its biogeochemistry and its ecosystems. Glacial fjords represent the bottleneck through which oceanic heat is delivered to the ice sheet margins, and through which meltwater, icebergs, and nutrients 


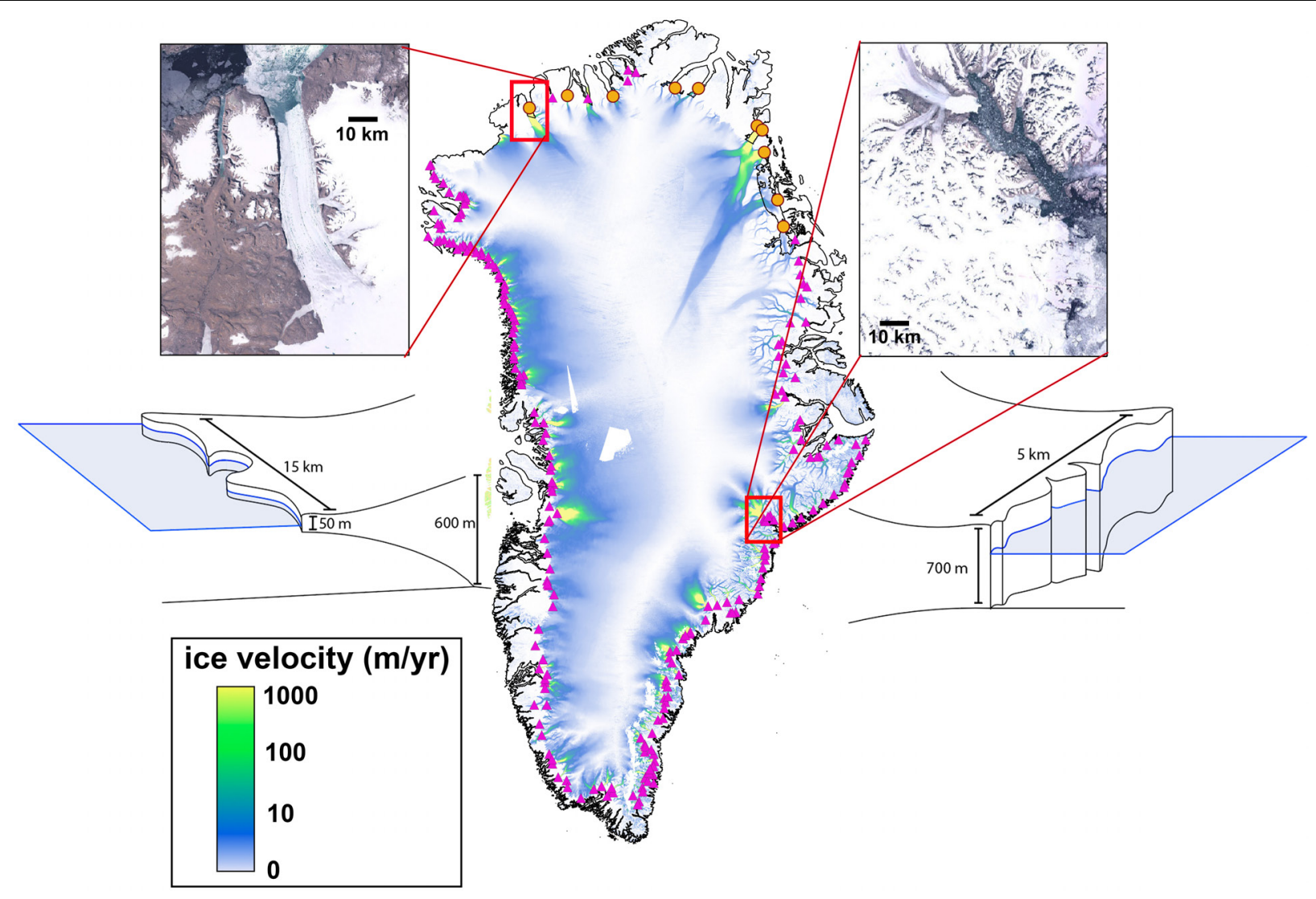

FIGURE 1 | The exchange of heat and freshwater between the ocean and the Greenland Ice Sheet occurs at the margins of over 200 marine terminating glaciers, visible as narrow areas of increased ice flow, distributed around the perimeter of Greenland that discharge into narrow, long and deep fjords. Several of these glaciers are characterized by long (>5 km) floating ice tongues (left inserts, orange circles) but most glaciers have lost their long floating regions (right inserts, pink triangles). Glaciers identified as having long floating ice tongues greater than $5 \mathrm{~km}$ in length, are determined through their height above floatation. Height above flotation is calculated using surface elevation data from the GIMP DEM (Howat et al., 2017) and ice bottom from BedMachine 3 (Morlighem et al., 2017). The background ice velocity is from a 2015-2016 mosaic (Joughin et al., 2017); glacier locations are from Rignot and Mouginot (2012).

(e.g., silica, iron, phosphorus) are exported into the global ocean (Figure 1). These glacial fjords are typically $\sim 100 \mathrm{~km}$ long and 5-10 km wide. Outlet glaciers in Greenland are often grounded in hundreds of meters of water. Only a handful of fjords in Northern Greenland have a floating ice tongue (Figure 1, left insets) that covers much of the fjord's extent (Wilson et al., 2017). Fjord topography, including the presence of a sill, regulates the exchange of water masses with the continental shelf, where both waters of Atlantic and Arctic origin coexist (Gladish et al., 2015; Carroll et al., 2017). Fjords with sills deeper than $\sim 100 \mathrm{~m}$ are characterized by a warm, Atlantic-sourced layer underneath a colder, fresher surface layer (Murray et al., 2010; Straneo et al., 2012; Inall et al., 2014; Mortensen et al., 2014).

Key processes that govern the exchanges of heat, freshwater, and nutrients at the ice/ocean boundary, and the upwelling of deep nutrient-rich ocean waters at the glaciers' margins, include localized plume upwelling driven by the subglacial discharge of ice sheet surface melt at glacier grounding lines (Jenkins, 2011; Xu et al., 2012; Sciascia et al., 2013; Kimura et al., 2014; Carroll et al., 2015; Cowton et al., 2015; Slater et al., 2015) and distributed melting along the glacier face (Figure 2). The circulation of waters in the fjord is thought to be regulated by a combination of buoyancy (Motyka et al., 2003), shelf-driven (Jackson et al., 2014; Fraser and Inall, 2018), and wind-driven forcings (e.g., Moffat, 2014; Spall et al., 2017). This circulation guarantees a continuous supply of heat to melt ice (see review by Straneo and Cenedese, 2015) and regulates the export of the strongly diluted meltwater (Beaird et al., 2015, 2017; Jackson and Straneo, 2016). Icebergs, commonly found next to calving glaciers, release meltwater throughout much of the fjord water column as they melt (Enderlin et al., 2014; Moon et al., 2017).

Subglacial discharge, i.e., ice sheet surface melt routed to the ice sheet base via the englacial drainage system (Noël et al., 2016; Van den Broeke et al., 2016; Langen et al., 2017; Wilton et al., 2017), has emerged as a major player in ice sheet-ocean interactions, since it amplifies ice sheet-ocean exchanges (e.g., Jenkins, 2011; Slater et al., 2015). Calving of icebergs, which balances most of the ice flux across the grounding line, is a poorly understood process that is likely influenced by climatic conditions and is a key regulator of glacier dynamics (Schoof et al., 2017). Efforts to extend the temporal record of ice sheet mass loss is the subject of considerable research (e.g., the 


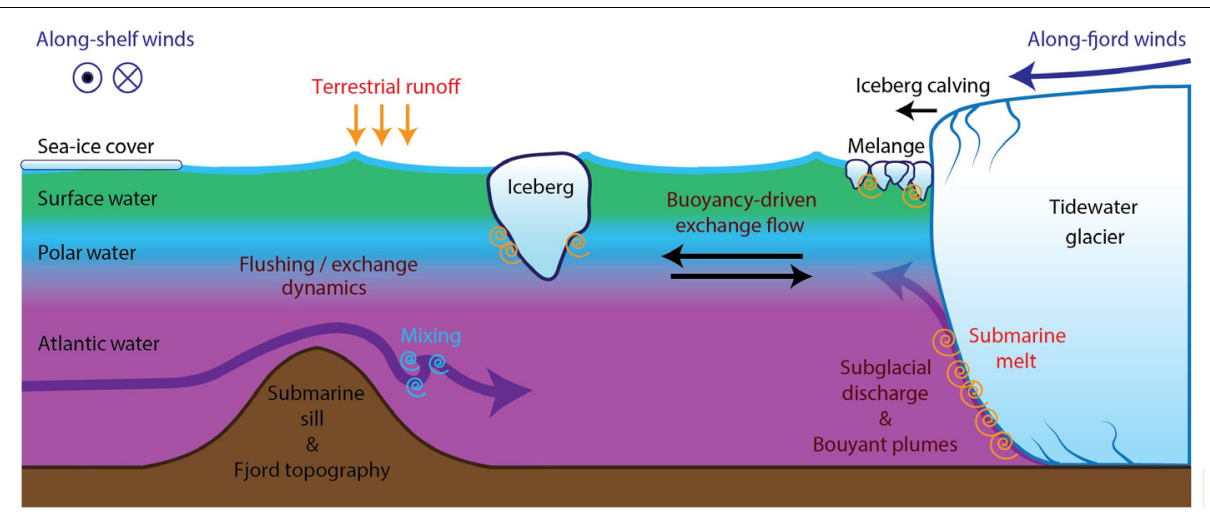

FIGURE 2 | Schematic of a Greenland glacier/fjord system showing relevant physical processes that govern circulation in the fjord and at the glacier-fjord boundary, typical stratification and water masses, and sources of freshwater to the fjord.

ongoing East GRIP Ice-Core Project focusing on the Northeast Greenland Ice Stream).

\section{Building a Case for GrIOOS: The Last Decade}

The rapid increase in mass loss from the GrIS began in the early 2000s (Krabill et al., 2004; Rignot et al., 2008; Murray et al., 2015; Catania et al., 2018; Wood et al., 2018) and it was only a decade later that the importance of processes at the ice sheet-ocean margins became apparent, making ice sheet-ocean interactions in Greenland and globally a novel and rapidly growing area of research. Key to community progress have been a series of workshops, and related follow-up documents, that sought for the first time to bring together the diverse disciplines needed to advance the science.

The first of these workshops, a multi-disciplinary International Workshop on "Understanding the Response of Greenland's Marine-Terminating Glaciers to Oceanic and Atmospheric Forcing," was organized by the US Climate and Ocean Variability, Predictability, and Change (US CLIVAR) Working Group on Greenland Ice Sheet-Ocean interactions in June 2013. It brought together over 100 international scientists and program managers with the goals to summarize the current state of knowledge and questions (Straneo et al., 2013) and to develop several key recommendations to make progress (Heimbach et al., 2014). One major recommendation was the collection of long-term time series (both in situ and remotely sensed) of critical glaciological, oceanographic, and atmospheric variables at key locations in and around Greenland through the establishment of GrIOOS. The research community recognized that such measurements are needed to provide information on the time-evolving relationships between climate forcing, ice sheet dynamics, and ocean characteristics. The lack of such data has hindered our ability to explain and model the complex interactions among ice-ocean-climate, leaving major gaps in our ability to project future changes. The community noted that GrIOOS data would be critical, not only to validate hypotheses, but also to provide boundary conditions, forcings, and a point of comparison for both ocean and ice sheet model simulations.
Following the recommendations made in the 2014 report, the Study of Environmental Arctic Change Land Ice Action Team, in collaboration with the Greenland Ice Sheet Ocean Interaction Science Network (GRISO), and the Climate and Cryosphere Project (CliC) of the World Climate Research Program, organized a workshop to make progress on the design and implementation of GrIOOS. The resulting 2015 workshop was attended by 47 participants from seven countries, including U.S. agency program managers (National Science Foundation, NSF, and National Aeronautics and Space Administration, NASA) and a representative of the Greenland government. Participant expertise included oceanography, glaciology, climate and ice sheet modeling, marine ecosystems, and paleoclimatology. Together, this group examined questions such as: (i) What are the essential ice sheet and ocean variables? What measurements and observing systems already exist? (ii) What should be the structure of the GrIOOS system regarding target observing sites and optimal instrumentation? (iii) How could data be collected, quality controlled, and distributed? Tentative answers to these questions are summarized in Straneo et al. (2018) and have informed the GrIOOS system design discussed here.

\section{Societal Benefits From GrIOOS}

Our inability to quantify GrIS-ocean exchanges, and their climate forcing, is a major scientific obstacle to understanding causal origins of past variability and to predicting the future of GrIS and its impact on the neighboring ocean regions, including the marine ecosystems. Connecting science across disciplines and countries, which is necessary to address key climate-related questions, has proven challenging because there is no integrating framework for a comprehensive ice sheet and ocean observing system, including needed structures for data management and dissemination, translating observations to usable model data and parameterizations, and overall cyberinfrastructure to support FAIR (Findable, Accessible, Interoperable, Re-usable) data.

The objectives of GrIOOS are to address all of these challenges by determining essential observations ('Essential Variables') for the ice sheet-ocean-atmosphere system, establishing guidelines for instrumentation that can be used across institutions and 
nations, creating metadata standards, establishing quality control best practices, and developing a user-friendly platform for FAIR data archiving, access and analysis. Fundamentally, these objectives support overarching goals to understand and project Greenland (and Arctic) ice sheet-ocean interactions and their impact on the ocean, including sea level rise. They explicitly contribute to two of the grand challenges issued to the international scientific community by the World Climate Research Programme and its subsidiaries, such as CLIVAR and CliC: (1) Melting ice and global consequences; (2) Regional sea-level change and coastal impacts.

GrIOOS will also serve other critical societal needs. Greenlandic communities rely on information about fjords, icebergs, and sea ice conditions for hunting and travel. Most of this information is based on personal experience and shared by word of mouth or social media. For coastal navigation and shipping, the ice service at the Danish Meteorological Institute (DMI) has a long history of mapping sea ice and icebergs hazards, especially around southern Greenland, for navigation purposes. The ice service is now automated and generates bi-weekly maps, taking advantage of Sentinel satellite imagery to give an overview of sea ice extent and iceberg distribution. With a GrIOOS program in place, we can create improved products that provide higher spatial resolution and, depending on the observation type, better temporal resolution. Such a program can also provide datasets that are requested by local hunters, fishers, policy makers, and business owners. Through coordination with colleagues at Asiaq Greenland Survey, this new or improved data can be shared with local communities in an easily usable, near-real time format, such as through an established GrIOOS data portal, or through appropriate media available to these communities. Asiaq also maintains an interactive Geographical Information System (GIS) website that is heavily used by the local community $^{1}$, which could provide an additional platform for data integration and access. The Government of Greenland has prioritized "strengthening the population's knowledge of climate change" and "disseminating information about climate change" as two of its four main research goals (GCRC, 2015). GrIOOS observations and cyberinfrastructure can support these goals.

International collaboration is also essential for regional engagement in the integration of science and traditional knowledge in ice sheet-marine coupling research. The Pikialasorsuaq partnership is a new collaboration between Greenland, Denmark, and Canada. The Pikialasorsuaq is the Inuit name for the North Open Water Polynya. This polynya is particularly important as a shared resource between Canada and Greenland, affecting biogeochemical processes at the northern limit of Baffin Bay (Barber and Massom, 2007). The governments of Canada, Greenland, and Denmark are currently discussing how to manage the Pikialasorsuaq region as an international shared resource. Based on the concept of a larger Baffin Bay Observing System (Rysgaard and BBOS Committee, 2017), the GrIOOS system will include an effort to bring traditional knowledge from communities surrounding the

\footnotetext{
${ }^{1}$ www.nunagis.gl
}

North Open Water polynya into the ice sheet-ocean observing system framework.

\section{VISION FOR A GREENLAND ICE SHEET-OCEAN OBSERVING SYSTEM}

The overarching vision for GrIOOS is the simultaneous observation of glaciological, oceanic, and atmospheric 'essential variables' (both in situ and remotely sensed) at ice sheet-ocean sites around Greenland, to be sustained over the coming decades. The observation should be sustained over multiple cycles of dominant atmospheric and oceanic modes of variability (e.g., National Academies of Sciences et al., 2016), in particular the North Atlantic Oscillation, Greenland Blocking, Atlantic Multidecadal Variability, and Pacific Decadal Variability. It should also cover the era of continuous satellite observations of several essential variables, which will be integrated with the in situ GrIOOS system and data.

The ensemble of GrIOOS sites should cover a range of ice sheet-ocean configurations, connect to all major oceanic basins around Greenland, be representative of the different climatic regimes, and capture systems thought to be dominant contributors to GrIS mass loss. The minimum set of essential variables to be collected at each site is motivated by present-day understanding of the key oceanic, glaciological, and atmospheric variables behind the processes that govern ice sheet-ocean exchanges of heat, freshwater, and nutrients. Additional inputs for any GrIOOS site are bathymetry and bed elevation. We refer to these as foundational datasets, which are critical but only need to be collected once. Ancillary measurements at a site, such as sediment cores that provide context for GrIOOS observations to be extended back in time, e.g., via paleo-proxy reconstructions (e.g., Andresen et al., 2012; Henry et al., 2016), or seismic and geodetic stations that connect GrIOOS to other scientific communities, are also highly desirable (e.g., Nettles and Ekström, 2010; Bevis et al., 2012).

The development and maintenance of GrIOOS will require close international collaboration. GrIOOS implementation will need to be coordinated amongst different countries, paying close attention to minimizing costs and optimizing shared logistics. Data processing protocols and data sharing practices must be identified, shared, and maintained. Quick, open, and centralized access to data is vital. Below we explain in detail the proposed GrIOOS framework.

In developing GrIOOS, we seek to follow the Framework for Ocean Observing (Task Team for an Integrated Framework for Sustained Ocean Observing, 2012) in an extended form that captures both the fundamentally multi-disciplinary nature of the ice sheet-ocean system, and the detail required to advance process level understanding.

\section{Identifying the Essential Variables of a GrlOOS Site}

Several key constraints are taken into consideration in identifying the ensemble of essential variables gathered at each GrIOOS site. First the ensemble of these variables should be sufficient input 


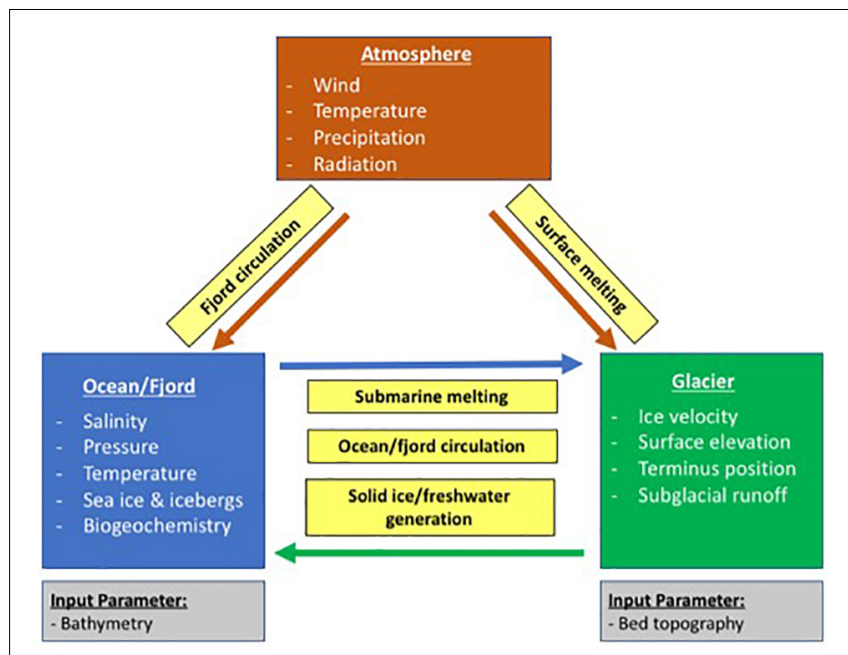

FIGURE 3 | Identified essential variables and their interconnection (inside boxes) at a GrlOOS site.

to algorithms or models that describe variations in the ice sheetocean processes that are relevant to addressing the questions identified above (Figure 3). Second, the essential variables should be practical to obtain, i.e., measurable and sustainable in terms of cost or derivation. Third, these variables should be relatively easy to relate to the larger scale oceanic, glaciological, and atmospheric context. Here, we summarize the relevant processes within the three focus areas identified above and identify essential variables that can represent their variability.

\section{Sea Level Rise}

Future sea level rise from the GrIS depends on mass loss through surface melt and through solid ice discharge of icebergs at the ice sheet-ocean boundary. Improving understanding of ice sheetocean interactions will inform research on the location and magnitude of ice sheet variability due to atmospheric and oceanic changes. To examine the ice sheet-ocean-atmosphere system, we have identified: ice sheet surface velocity; ice sheet surface elevation (and ice thickness via bed topography data); terminus position; surface runoff and subglacial discharge as the minimum set of essential variables (Table 1).

Ice sheet surface velocity, combined with ice thickness and grounding line information, can be used to calculate ice flux at marine termini around Greenland (e.g., Rignot et al., 2011; Enderlin et al., 2014). Time-series of these variables are also essential in unraveling the processes governing flow variability (e.g., Stearns and van der Veen, 2018). Acceleration, thinning, and retreat often occur near-coincidentally, driven by processes at the ice-bed and ice-ocean interface that are impossible to observe directly.

Frontal ablation at the ice-ocean interface, which includes submarine melting and iceberg calving, all influence ice sheet behavior and ice loss (Straneo et al., 2013; Kjeldsen et al., 2017). Submarine melting is largely thought to be controlled by the thermal forcing of the ocean waters reaching the glacier (Figure 2), and is amplified by large ocean velocities, such as those due to subglacial discharge driven turbulent, upwelling plumes at the glaciers' margins during the melt season (Mortensen et al., 2013; Bendtsen et al., 2015; Mankoff et al., 2016; Jackson et al., 2017). Calving is accelerated in regions undercut via submarine melting (described above; Bartholomaus et al., 2013; Chauché et al., 2014; Fried et al., 2015), but can also occur when the terminus reaches flotation and basal crevasse propagation leads to full-thickness calving (James et al., 2014; Murray et al., 2015). Essential observations needed to constrain submarine melting: are subglacial discharge, and ocean temperature and salinity as a function of pressure (Table 1), The essential observations of terminus position and ice velocity, combined with calculations of submarine melt will inform research on calving processes, ice sheet response to ocean change, and, ultimately, sea level rise.

\section{Freshwater Export}

Glaciers release freshwater at the ice sheet-ocean margins as solid ice (icebergs) and meltwater. Meltwater enters the fjords as surface runoff, submarine melt across the termini, or subglacial discharge (Figure 2). Icebergs undergo considerable melting as they transit through the fjords, giving rise to an additional meltwater flux (distributed along the iceberg depth) and a residual iceberg export at the fjord's mouth. This melting, in turn, is largely controlled by the fjord circulation and temperature structure. The export is controlled by local winds, the fjord circulation and fjord bathymetry.

Meltwater released at depth along the glacier face (submarine melt and subglacial discharge) creates plumes that rise, entrain large volumes of deep fjord waters, and produce a much greater transport than the volume of meltwater released (e.g., Motyka et al., 2003; Beaird et al., 2018). While the details of the processes controlling the dilution and export of the meltwater and of icebergs, from the glacier and fjord, are complex, they are thought to be largely controlled by: (1) the release of subglacial discharge and surface runoff; (2) the iceberg flux; (3) the temperature of the fjord waters; (4) the fjord circulation; (5) local winds. These in turn, can be described in terms of the surface mass balance components, the calving flux, properties inside the fjord and on the nearby shelf (since this gradient controls the fjord/shelf exchange), local and regional winds. Note that while it would be highly desirable to include fjord velocities (or circulation) as an essential variable, these measurements are costly and largely uncertain due to the high spatial and temporal variability of velocities in these narrow fjords (Mortensen et al., 2014; Jackson and Straneo, 2016; Boone et al., 2017). Information about iceberg distribution and sea ice coverage is also critical for classifying ice hazards, which is a crucial metric for shipping, industrial development, and local community activities in the marine areas surrounding Greenland (e.g., Barber et al., 2014).

\section{Impact on Biogeochemistry and Ecosystems}

The timing, mode of delivery, properties, and magnitude of freshwater export into the ocean fundamentally shape ocean biogeochemistry. Plumes of meltwater and entrained ocean waters rising at the glacial margin drive a vertical transport of dissolved nutrients and sediments toward the surface 
TABLE 1 | GrlOOS essential variables, with information about readiness levels for component requirements, observation instruments and methods, and data and information systems.

\begin{tabular}{|c|c|c|c|c|}
\hline Component & Essential Variable & Requirements & Observations & Data and Information \\
\hline \multirow[t]{4}{*}{ Ocean: hydrography } & Temperature & Mature & Concept* & Mature \\
\hline & Salinity & Mature & Concept* & Mature \\
\hline & Irradiance & Mature & Concept* & Mature \\
\hline & Chl-a fluorescence & Mature & Concept* & Mature \\
\hline \multirow[t]{5}{*}{ Ocean: biogeochemical } & Dissolved Oxygen & Mature & Concept* & Mature \\
\hline & Turbidity & Mature & Concept* & Mature \\
\hline & Nitrate & Mature & Concept* & Mature \\
\hline & $\mathrm{pCO}_{2}$ and $\mathrm{pH}$ & Mature & Concept* & Mature \\
\hline & Iceberg production & Pilot & Concept & Concept \\
\hline \multirow[t]{4}{*}{ Ocean: ice-related } & Iceberg distribution & Pilot & Concept & Concept \\
\hline & Sea ice concentration & Pilot & Concept & Concept \\
\hline & Surface velocity & Mature & Mature & Mature \\
\hline & Terminus position & Mature & Concept & Concept \\
\hline \multirow[t]{4}{*}{ Ice } & Surface elevation & Mature & Mature & Mature \\
\hline & Surface runoff & Mature & Mature & Mature \\
\hline & Subglacial discharge & Mature & Concept & Mature \\
\hline & Temperature & Mature & Mature & Mature \\
\hline \multirow[t]{3}{*}{ Atmospheric } & Wind & Mature & Mature & Mature \\
\hline & Precipitation & Mature & Mature & Mature \\
\hline & Radiation & Mature & Mature & Mature \\
\hline
\end{tabular}

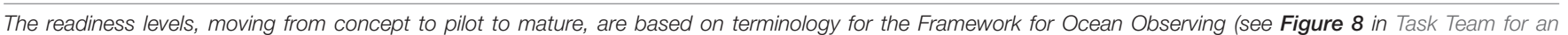

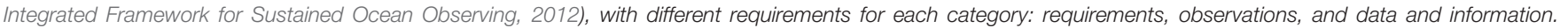
* Locational challenges add to 'concept' classification.

ocean, where they can impact the growth of phytoplankton by respectively fueling primary production or altering light penetration and optical properties. Measurements of nitrate, a primary limiting nutrient present in low concentration in meltwater but abundant in the deep ocean, alongside turbidity, in this way serve as essential tracers for iceocean exchanges and glacier-driven circulation, as well as nutrient availability. The response of phytoplankton to glacial modification of upper water column physical and chemical properties can in turn be examined through measurement of chlorophyll-a fluorescence and dissolved oxygen. Alongside measurements of ambient light, these parameters can, in concert, give insight into primary productivity rates and the biomass of organic carbon available to higher trophic levels, important ecosystem properties. The integrated response of the carbon cycle to ice-ocean exchanges, including the overall magnitude and sign of the atmosphere-ocean carbon flux, is a function of both biological cycling and thermodynamic effects stemming from physical mixing of glacial and ocean water masses (Meire et al., 2015). Time series of $\mathrm{pCO}_{2}$ and $\mathrm{pH}$, alongside biological parameters previously described, are therefore essential variables to constrain carbon cycle response (Figure 3).

\section{The Relevant Essential Variables}

Based on a summary of the processes and major controlling variables outlined above, and in consideration of both feasibility and reliability of existing technologies for longterm measurement, we suggest the following essential oceanic, glaciological, and atmospheric variables for each GrIOOS site (Table 1):

- Oceanic variables include temperature and salinity as a function of pressure both within the fjord and across the nearby shelf. Sea ice cover, iceberg production, and iceberg distribution are also essential. Biogeochemical variables needed to characterized productivity include downwelling irradiance, chlorophyll-a fluorescence, and dissolved oxygen. Turbidity and nitrate are needed to quantify seasonality in nutrient availability associated with glacial discharge and fjord circulation. Finally, $\mathrm{pCO}_{2}$ and $\mathrm{pH}$ are needed to constrain the carbon cycle response. Tracking of properties both inside the fjord and on the nearby shelf is needed to separate remote and local drivers of variability.

- Glaciological variables include ice velocity, surface elevation, ice thickness (via bed and surface elevation), terminus position, surface melt (i.e., that generates surface runoff) and subglacial discharge. These variables will allow us to calculate iceberg calving rates, ice volume changes, and freshwater discharge at the GrIS marine margin.

- Atmospheric variables include local weather data (winds, air temperature, precipitation, radiation, etc.) to provide information essential to estimating the regional and fjordscale atmospheric forcing of the ice sheet and ocean surface.

- Additional foundational datasets critical for any GrIOOS site are bedrock and ocean bathymetry. 


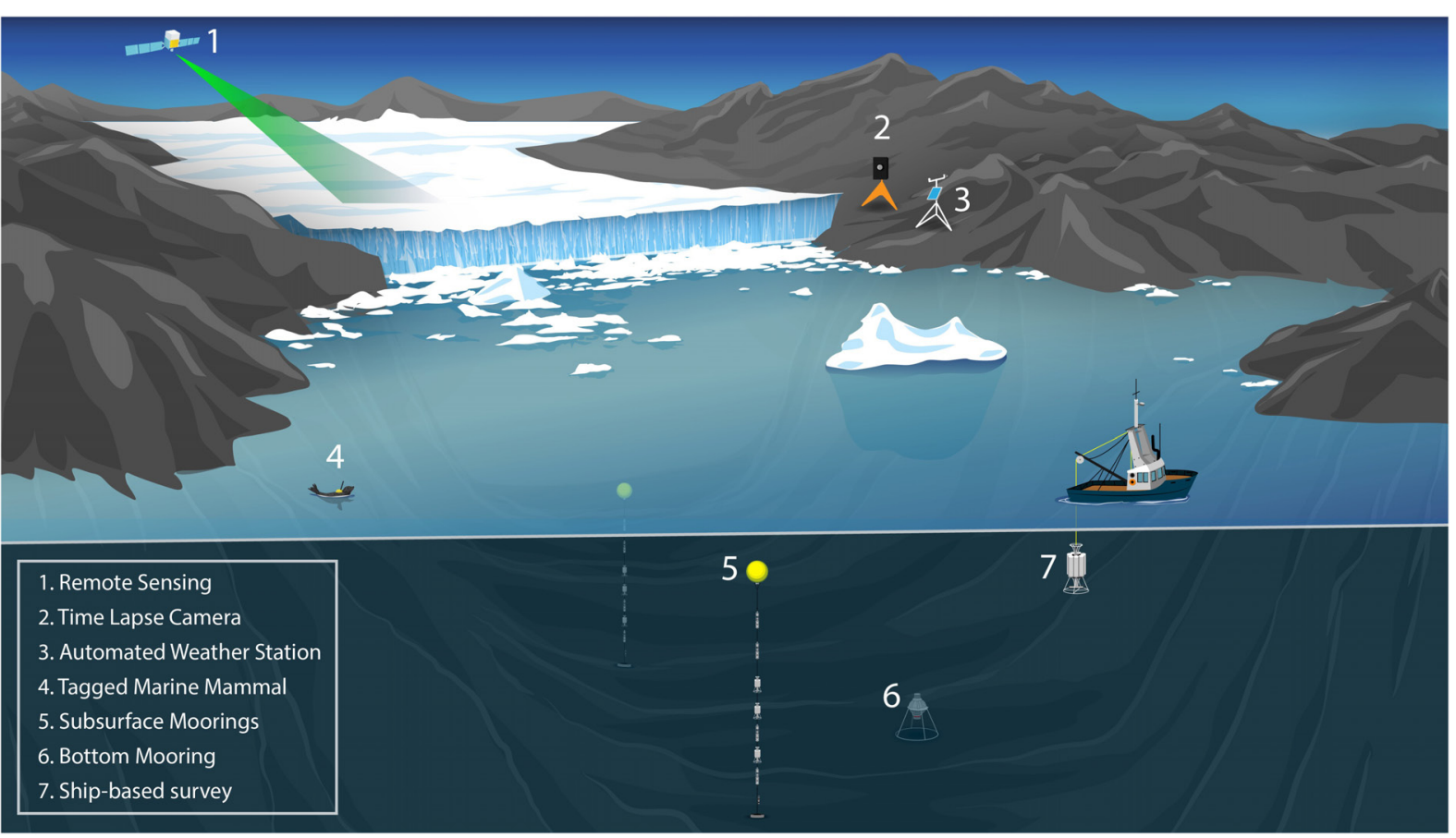

FIGURE 4 | Example of potential instrumentation for a GrlOOS site located at the margins of a tidewater glacier (note: not to scale).

\section{How to Get the Essential Variables for Each GrIOOS Site}

It is envisioned that the essential variables described above (and in Table 1) will be gathered at each site either as in situ measurements or as derived quantities from, for example, remote sensing. A generic GrIOOS site is depicted in Figure 4. For all essential variables, there is a strong need for year-round observations. High temporal resolution (as often as hourly to weekly depending on variable) measurements are required since it is unclear which timescales govern both the oceanic forcing and the glacier response, or whether threshold behavior exists that only bears out during certain environmental conditions. Engagement with communities located near GrIOOS sites will be a key part to the temporal sampling required.

\section{Ocean}

Ocean essential variables require year-round measurements both in the glacier vicinity (typically in the fjord) and on the nearby continental shelf. Depending on the fjord/glacier type, the way these measurements are achieved may differ substantially. Floating ice shelves (or 'floating tongues') offer the possibility of suspending instruments from the ice through bore holes that are expensive to drill but provide ideal platforms. Tidewater glaciers with substantial calving are challenging because of the deep draft icebergs and general inaccessibility of the region. These require site specific strategies that may include subsurface moorings (Figure 4). Sensors deployed on marine mammals may be appropriate for some sites where other technologies are deemed impractical. Biogeochemical sensors present additional challenges that will also necessitate site-specific strategies.
A subset of biogeochemical sensors (e.g., fluorescence, $\mathrm{O}_{2}$, $\mathrm{pCO}_{2}, \mathrm{pH}$ ) need to be deployed in the upper 10-50 $\mathrm{m}$ of the water column where major biological processes and freshwater export take place. By contrast, sensors used to characterize links between physical processes and chemical properties of the ocean (e.g., nutrient fluxes and distributions) may in certain cases be deployed subsurface.

The size and distribution of icebergs in fjords and the surrounding ocean are important to characterize for their impact on freshwater- and nutrients dynamics. New efforts to quantify iceberg distributions are now possible given the robust temporal coverage of both optical and radar satellite imagery over the Arctic. Ocean nodes should integrate remote sensing results of both iceberg distribution and sea ice coverage, which are essential for freshwater flux calculations (Moon et al., 2017; Sulak et al., 2017). Iceberg detection from Sentinel satellites around Greenland has been automated by the DMI and daily plots for several distinct locations are displayed on the Danish public outreach website polarportal.dk, based on the methods of Buus-Hinkler et al. (2014) but at finer spatial resolution of 40 and $10 \mathrm{~m}$. While this technique is able to distinguish icebergs at unprecedented resolution, it shares, with other remote sensing data products, the disadvantages of limited temporal and spatial coverage and is not capable of distinguish icebergs trapped within sea ice or mélange in front of calving outlet glaciers. Finally, it is notable that despite the large fraction of discharge from the GrIS occurring as solid ice, little information is available concerning how icebergs affect nutrient cycling within Greenland's fjords, making iceberg observations also critical for ocean biogeochemistry. 


\section{Glacier}

Most glacier essential variables (ice surface velocity, terminus position, ice sheet surface elevation) can be acquired via remote sensing sensors already in orbit and mature analysis techniques. Some variables can already be acquired from consistently archived and served data streams and will not require significant GrIOOS investment. For example, both optical and radar satellites now allow weekly to monthly measurements of ice surface velocity, which is systematically processed and served through U.S. and European data archives. Some datasets, however, require further GrIOOS science and research development. In particular, terminus position is not currently provided in a systematic way, largely consisting of sporadic terminus shapefiles available from individual investigators. Existing networks and data sets to support development of glacier and ice sheet essential variables are discussed in Section "Glacier and Ice Sheet." Additional in situ observations of the outlet glacier system could also take advantage of ocean deployments for additional sensors to improve understanding with satellite-based observations and time-lapse cameras to provide high temporal and spatial information (Figure 4). The best current source for surface mass balance information are regional climate models (see Dynamical and Statistical Reconstructions). We envision essential variables will be linked on a website that would bring together the disparate data sets for the general purpose of quantifying the spatio-temporal variability in glacier behavior (see Data Protocol and Management).

\section{Atmosphere}

The atmosphere node provides variables that support both glacier and fjord measurements. At the local scale measurements are obtained via Automated Weather Stations (AWS; Figure 4). AWS deployed at locations adjacent to the glacier terminus can provide essential variables (air temperature, winds, precipitation, radiation) and other standard meteorological observations (Table 1). These data can also improve remote sensing and reanalysis products. Depending on the location, such measurements may be available through several of the existing meteorological station networks, e.g., DMI, see Weather Station Data). At the regional scale, estimates of air temperature, winds, pressure, and other meteorological parameters are available through regional climate model or global atmospheric analysis, forecast or reanalysis products (see Dynamical and Statistical Reconstructions). These data will fulfill many of the variable needs for capturing regional-scale atmospheric conditions over the glacier-fjord-continental shelf system. In addition, large-scale circulation indices, such as the Greenland Blocking Index (Hanna et al., 2016, 2018), will be helpful for contextualizing ice sheetatmosphere-ocean interactions.

\section{Foundational Datasets: Bathymetry and Bed Elevation}

Ice sheet bedrock topography and fjord bathymetry are critical foundational datasets. Significant efforts have been made over the last decade to improve estimates of ice sheet bed elevation, particularly beneath the outlet glaciers of the GrIS, with airborne ice-penetrating radar (Leuschen et al., 2018). In addition, new bathymetric and airborne gravity surveys within multiple glacier fjords in Greenland have been made over the last few years as interest in ice sheet-ocean interactions has increased (e.g., Fenty et al., 2016; Rignot et al., 2016; Kjeldsen et al., 2017; Millan et al., 2018). These provide an even more detailed picture of the topography beneath glacier termini and within the fjord. Together, these types of observations have been used to construct a seamless bed elevation product across the GrIS ice sheet-ocean margin using a mass-conservation approach that provides a best estimate for the bed topography constrained by observational data (Morlighem et al., 2011, 2017). Since these new data use both ice-penetrating radar and bathymetric data, grounding line depth estimates have improved dramatically over previous estimates and provide a more accurate picture of the geometric setting for critical outlet glaciers terminus regions. Even with these improvements, many outlet glaciers (adjacent) within the GrIS have not been surveyed with ice penetrating radar (bathymetric mapping) and are poorly constrained in the mass-conservation inversion. Any additional bedrock/bathymetric data collected as part of GrIOOS should therefore be readily made available to improve the existing database.

\section{Characteristics of GrIOOS Sites}

The ensemble of GrIOOS sites should span a range of geometries that take into account the glacier/fjord depths, fjords with and without sills, glaciers with and without floating termini, and different oceanic basins. Choice of the sites should take into account existing measurements, noting sites that are already being monitored that could become GrIOOS sites with minimum additional measurements. Proximity of other observing networks (see below) to sites can optimize sustainability, provide broader context, and allow shared logistics costs. Sites close to inhabited or regularly serviced centers allows for accessibility at reduced costs and may be a source of information to the local community. There should be a focus on the largest contributors to Greenland Ice Sheet mass loss, and the proximity of paleo records should also be taken into account.

At the initial GrIOOS development meeting, several possible observational sites were suggested based on voting of each participants' top three sites and the considerations described above, such as existence of ongoing observations, logistical support, scientific rationale, and societal rationale. The glacier/fjord sites with the most votes were Helheim Glacier/Sermilik Fjord, 79 N/NE Greenland Ice Stream (NEGIS), and Jakobshavn Isbrae/Ilullisat Icefjord, with additional priority sites listed here in order of voting (Table 2). The top three sites are dominated by glaciers that calve via full-thickness events and where melt-induced terminus change may play a reduced role (Fried et al., 2018). In a fully implemented GrIOOS, care should be taken to include a broad range of glacier settings, defined by the glacier dynamic behavior, and fjord settings, defined by geometry and proximity to distinct open ocean regions.

Additionally, during the previous GrIOOS workshop, participants helped to identify and discuss lessons learned from other ongoing observational programs, such as the Geological Survey of Denmark and Greenland (GEUS) Program for Monitoring of the Greenland Ice Sheet (PROMICE), or 
TABLE 2 | Characteristics of potential GrlOOS glacier-fjord sites, including the ocean basin adjacent to link to existing open ocean measurements, the fjord and glacier geometry to ensure a diversity of glacier/fjord types, Greenland sector, and whether in situ measurements of ocean (O), ice (I), atmosphere (A), and ecosystem (E) variables exist now or in the past.

\begin{tabular}{|c|c|c|c|c|c|c|c|}
\hline Fjord/Glacier System (Figure 5 label) & Greenland Sector & $\begin{array}{c}\text { Adjacent } \\
\text { Ocean } \\
\text { Basin }\end{array}$ & $\begin{array}{l}\text { Max Fjord } \\
\text { Depth (m) }\end{array}$ & $\begin{array}{l}\text { Sill depth } \\
\text { (m) }\end{array}$ & $\begin{array}{l}\text { Grounding } \\
\text { line depth } \\
\text { (m) }\end{array}$ & $\begin{array}{c}\text { Ice flux } \\
\text { (km³/year) }\end{array}$ & $\begin{array}{l}\text { Existing } \\
\text { in situ } \\
\text { observation }\end{array}$ \\
\hline Sermilik Fjord/Helheim Gl. (HG) & Southeast & $\begin{array}{l}\text { Irminger } \\
\text { Sea }\end{array}$ & 920 & $\mathrm{~N} / \mathrm{A}$ & 700 & 16 & $\mathrm{O}, \mathrm{I}, \mathrm{A}, \mathrm{E}$ \\
\hline NEGIS ${ }^{a} / 79 N$ (NEGIS) & Northeast & Fram Strait & 800 & 200 & 600 & 9 & $\mathrm{O}$ \\
\hline Ilulissat Icefjord/Jakobshavn Isbrae (JI) & Central West & $\begin{array}{l}\text { Labrador } \\
\text { Sea }\end{array}$ & 800 & 250 & 1000 & 21 & $O, I, A$ \\
\hline Petermann Glacier ${ }^{a} /$ Fjord (PG) & North/Northwest & Nares Strait & 810 & 440 & 610 & 6 & $\mathrm{O}, \mathrm{I}, \mathrm{A}$ \\
\hline Rink Isbrae/Karrats Isfjord (RI) & Central West & $\begin{array}{l}\text { Labrador } \\
\text { Sea/Davis } \\
\text { Strait }\end{array}$ & 1200 & 430 & 840 & 9 & $\mathrm{O}^{b}$ \\
\hline Kangerlug- ssuaq Glacier/Fjord (KG) & Southeast & $\begin{array}{l}\text { Irminger } \\
\text { Sea/Denmark } \\
\text { Strait }\end{array}$ & 880 & $\mathrm{~N} / \mathrm{A}$ & 700 & 13 & $\mathrm{O}^{b}$ \\
\hline Upernavik $^{C}$ Glacier/Fjord (UG) & Northwest & Baffin Bay & 900 & $\mathrm{~N} / \mathrm{A}$ & $100-700$ & $2-4$ & $\mathrm{I}, \mathrm{A}$ \\
\hline Bowdoin Glacier/Fjord (BG) & Northwest & Baffin Bay & 600 & 200 & 250 & 0.5 & $O, I, A$ \\
\hline Kangiata Nunaata Sermia/Godthabsfjord (KNS) & Southwest & $\begin{array}{l}\text { Labrador } \\
\text { Sea }\end{array}$ & 600 & 200 & 250 & 7.5 & $O, I, A, E$ \\
\hline
\end{tabular}

The listed order represents the number of votes obtained for developing each glacier/fjord system as a GrIOOS site (see text). a The Northeast Greenland Ice Stream/79

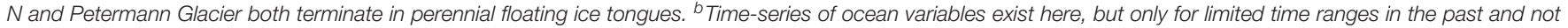
at present. ${ }^{C}$ Ranges are given since four glaciers flow into Upernavik Fjord (Ah/strøm et al., 2013).

through the Global Ocean Observing System Framework for Ocean Observing (Task Team for an Integrated Framework for Sustained Ocean Observing, 2012). Several potential key requirements were identified:

- Light and sustainable: Logistically or instrumentally expensive observing systems are difficult to maintain over time. Simple logistics, and ones that would make use of interested communities, are best. However, previous efforts [e.g., US Geological Survey (USGS) monitoring for mountain glaciers] have shown that it is best to aim for oversampling during the first several years of the observing system, with the objective to identify key sites for sustained observations, accommodating potential needs to scale down the observing system over time.

- Monitoring requires proven technology: Although testing new technology is an interesting prospect if it can reduce later costs, an observing system is not the best place to implement new technologies.

- Build on available logistics and programs: Although programs that are already running would not easily scale up, they can provide logistical support for additional instrumentation deployment, if necessary.

\section{EXISTING NETWORKS}

Interest in the GrIS and surrounding fjords and ocean has grown rapidly over the last few decades and led to an expansion of monitoring networks both in situ and from remote sensing observations (Figure 5). GrIOOS will be developed to connect with and leverage these existing networks. In particular, the connection with regional programs will provide the needed 'farfield' connection of GrIOOS' sites to the ocean (continental shelf and large scale ocean); the ice sheet and the atmosphere. Here, we outline a number of these existing research and observation activities (see Figure 5 for location).

\section{Ocean}

\section{Moored Arrays}

The mooring array in Fram Strait (de Steur et al., 2014) to measure Arctic Outflow was deployed in 1997 as a government funded monitoring system collaboration between Norwegian Polar Institute (Norway) and the Alfred Wegener Institute (Germany). The array records temperature, salinity, currents, ice thickness and ice drift, and is complemented by annual conductivity/temperature/depth (CTD), lowered acoustic Doppler current profiler (LADCP) and tracer transects in August and September (Figure 5). It is expected that it will be maintained for at least another decade. The array is concentrated in deeper water and lacks moorings on the Greenlandic continental shelf (due to ice hazards), however, repeat CTD transects are conducted on the shelf whenever possible.

A mooring array across Davis Strait was deployed in 2004 as a US-Canadian collaborative project to measure Arctic outflow west of Greenland (Curry et al., 2014). The mooring array spans across the continental shelves (Figure 5) and measures velocity, temperature, salinity, sea ice thickness. It is supplemented by marine mammal acoustics, year-round glider observations, and annual or biennial hydrographic sections. Hydrographic measurements also include macro-nutrient concentrations (i.e., nitrite plus nitrate, silicate, phosphate, ammonium) and oxygen 


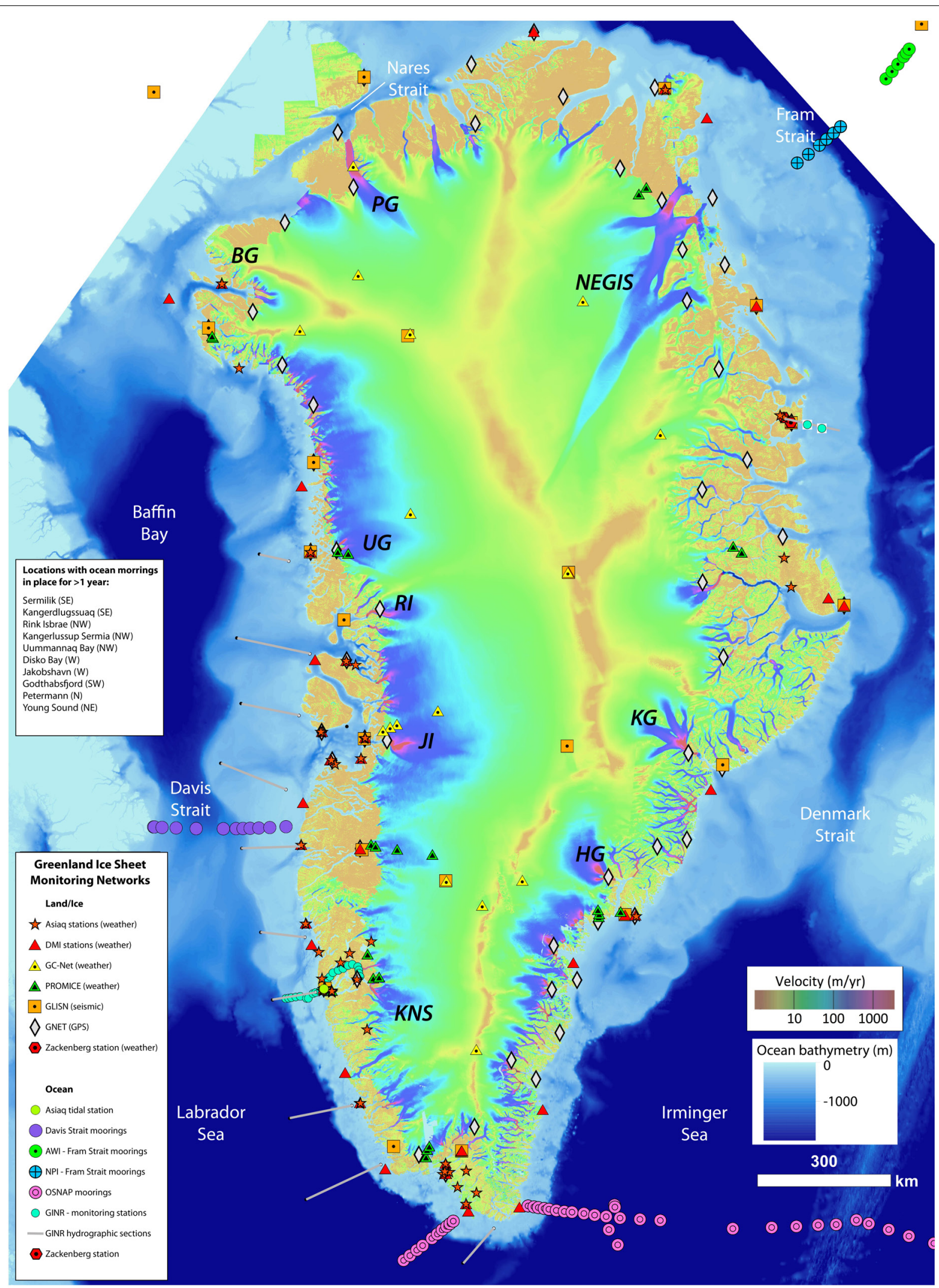

FIGURE 5 | Map of primary existing in situ networks and long-term measurements around Greenland, overlaid on a map of ice velocity (Joughin et al., 2011) and bathymetry (Morlighem et al., 2017). Glaciers listed in Table $\mathbf{2}$ are identified using labels from Table 2. 
isotopes $\left(\delta^{18} \mathrm{O}\right)$. The future of the network is uncertain and dependent on funding.

Overturning in the Subpolar North Atlantic Program ${ }^{2}$ is an international trans-basin observing system to measure the meridional overturning circulation through mooring arrays (Figure 5), repeat hydrographic transects, and glider deployments (Lozier et al., 2017). The observing network, which includes two mooring arrays on the southeast and southwest Greenland shelves and slopes, was installed in 2014 and currently funded through 2020 . It is expected that it will be maintained for a decade.

\section{Hydrographic Surveys}

The Greenlandic fisheries industry has records, dating back to 1990, of bottom temperature collected during bottom trawler shrimp density surveys off the southwest coast (e.g., Holland et al., 2008). Approximately $50 \%$ of the stations are reoccupied annually. The Icelandic mackerel survey on the east coast has hydrographic measurements starting from 2013 that extend from Greenland to Iceland and Norway.

Hydrographic transects in Godthåbsfjord have been conducted since 2007 by the Greenland Institute of Natural Resources (GINR) and include measurement of physical, biological, and chemical variables (Figure 5). Ice-free conditions in the fjord mean this survey is conducted year-round from small vessels. One station near Nuuk is monitored monthly, where a suite of ecosystem sampling is conducted in concert with the hydrographic observations. Ecosystem monitoring is being carried out only at a few other sites around Greenland, but resources are limited and marine ecosystem observations only begin in 2002. Moorings have been maintained during the last decade at several locations.

Hydrographic transects in West Greenland: GINR also monitors across the continental shelf of west Greenland during yearly surveys (Figure 5) in June and $\mathrm{July}^{3}$; previously these surveys were handled by DMI on behalf of the Greenland Institute of Natural Resources (e.g., Myers et al., 2009). Additionally CTD measurements are collected inshore during yearly fishery surveys in Maniitsoq, Disko Bay, Uummannaq, and Upernavik.

The Oceans Melting Greenland project is a 5-year NASA program that began in 2015 to observe water temperatures around the coast of Greenland (Figure 5) and measure how marine terminating glaciers react to the presence of Atlantic Water (Fenty et al., 2016). The project consists of annual aerial ice topography measurements and gravimetry of glacier margins and the deployment of 250 Airborne expendable CTD probes (AXCTDs) to measure the properties and extent of Atlantic Water around the coast.

The GEOTRACES project is an ongoing, coordinated international activity to quantify the supply, removal, and distribution of bioessential micronutrients (such as iron) in the ocean. The completed cruise sections GA01 (North Atlantic/Labrador Sea), GN02 (Labrador Sea/Baffin Bay) and

${ }^{2}$ www.o-snap.org

${ }^{3}$ https://archive.nafo.int/open/sc/2015/scr15-001.pdf
GN05 (Fram Strait) provide an invaluable dataset to measure trace chemical species in the ocean around Greenland. The GN05 section was notable for proceeding to sample within close proximity to the $79 \mathrm{~N}$ glacier and the GA01 section includes shallow shelf stations which show a terrestrial influence on shelf water properties. Whilst the GEOTRACES program has an intentional offshore focus, there is now a clear possibility of process studies to bridge the gap between these extensive offshore sections and fjord/shelf regions to understand how far offshore meltwater and glacially derived particles influence the biogeochemical cycling of essential micro-nutrients in the ocean.

The Labrador Sea Monitoring Program of Fisheries and Oceans Canada has collected physical, chemical, and biological observations along a hydrographic transect across the Labrador Sea (corresponding to Atlantic Repeat Hydrography Line 7 West of the World Ocean Circulation Experiment) since 1990. Measurements span Hamilton Bank on the Labrador Shelf to Cape Desolation on the Greenland Shelf. The transect is occupied annually, although frequency is dependent on funding (Yashayaev and Loder, 2017).

\section{Autonomous Sampling}

Large scale ocean properties can be obtained from the Argo float program that, since 2006, maintains a global array of more than 3000 free-drifting profiling floats that measure hydrographic properties in the upper $2000 \mathrm{~m}$ of the ocean (Roemmich et al., 2009). This program is complemented by the Biogeochemical-Argo float program (Claustre et al., 2010; Gruber et al., 2010), which alongside physical parameters collects biogeochemical measurements. These floats are not useful on the Greenland continental shelf but do provide boundary conditions to monitor long-term average ocean basin property changes around Greenland.

Water property information is also obtained by tagging marine mammals, and a central repository for these data already exist in the international Marine Mammals Exploring the Ocean Pole to Pole program (Treasure et al., 2017). These temperature/salinity profiles provide useful data on the continental shelves (e.g., Sutherland et al., 2013) or offshore (Laidre et al., 2010; Grist et al., 2014), and are potentially a way forward for collecting more in situ data inside fjords (e.g., Mernild et al., 2015) as well as a connection to the ecosystem response of higher-trophic level animals influenced by Greenland's glacial fjords (Laidre et al., 2016).

\section{Remote Sensing}

Remote sensing data products can provide important oceanographic information (such as sea surface salinity and temperature), but are not currently generated at the scale that is useful for GrIOOS. A few of these products are potentially useful for fjord-scale processes, such as subglacial outlet plumes, sea-ice cover, iceberg drift and biological productivity (ocean color). However, satellites are limited in their ability to observe subsurface features (e.g., phytoplankton blooms, glacial and sediment plumes) that are relevant to GrIOOS science goals. Sea surface height can be measured via satellite altimetry, but with challenges near the coast and with limited 
coverage at high latitudes (Cipollini et al., 2016). Sediment plumes can be monitored by MODIS Aqua/Terra and Landsat 8 , and ocean color measurements (characterizing biomass of primary producers and productivity) are collected by SeaWiFS, MODIS, and Sentinel 3-A, among others. Most of these variables, however, are considered ancillary to the essential ocean variables for GrIOOS.

Remote sensing of sea ice can include active and passive microwave estimates of the thermodynamic state of fast-ice fringes of sea ice, sea ice drift estimates (including export pathways on the west and east sides of Greenland), presence of significant freshwater sea ice, sea ice dynamic properties through coupling to glacier solid and liquid phase fluxes, and estimates of the optical properties of the sea ice through microwave-optical radiative transfer techniques (e.g., Barber, 2005). Specifically, both Landsat (optical) and Sentinel (optical, radar) satellite imagery can be used to identify sea ice distributions near the Greenland coast. The combination of Landsat and Sentinel imagery allows for the near-daily classification of features after 2016. Prior to the launch of the Sentinel satellites, repeat observations with Landsat occur every 16-18 days since $\sim 1999$. Note that even medium resolution sea ice concentration products, such as 4-km Multisensor Analyzed Sea Ice Extent data (and, in 2015-2016, 1-km resolution data), fail to provide accurate sea ice concentrations in Greenland fjords. Future GrIOOS efforts would include the systematic production of these data at temporal and spatial scales relevant for fjord dynamics.

\section{Glacier and Ice Sheet Surface Speed}

Both optical and radar remotely sensed data can be used to derive velocity data. Optical data has the benefit of multiple bands of data, which can be useful for co-processing velocity with other information, but imaging the ice surface through clouds or darkness is not possible. Radar data avoid these problems but does not include additional bands of data. Satellite coverage for both optical and radar data has expanded substantially over the last two to three decades, with additional satellite launches for both optical and radar instruments planned within the next few years. Velocity data are now available in weekly to monthly time resolution via projects including GoLIVE (Global Land Ice Velocity from Landsat 8 Extraction $^{4}$ ); ITSLIVE (Intermission Time Series of Land Ice Velocity and Elevation), which will begin in 2019; and NASA MEaSUREs ${ }^{5}$, all with key glaciological data hosted at the National Snow and Ice Data Center. Velocity data are also available for more limited areas via the ENVEO Cryoportal $^{6}$, CPOM Data Portal ${ }^{7}$, and Technische Universitat Dresden $^{8}$. The European Space Agency's (ESA) climate change initiative for the GrIS has operationally produced a number of relevant remote sensing data products including ice sheet velocity, calving front position, surface elevation change and

\footnotetext{
${ }^{4}$ nsidc.org/data/golive

${ }^{5}$ nsidc.org/data/measures

${ }^{6}$ cryoportal.enveo.at

${ }^{7}$ www.cpom.ucl.ac.uk/csopr/iv

${ }^{8}$ datal.geo.tu-dresden.de/flow_velocity
}

grounding line position. These datasets are updated semiannually and are freely available (e.g., Mottram et al., 2018).

\section{Terminus Position}

As a result of recent interest in the various processes influencing glacier termini there has been renewed interest in tracking glacier terminus changes over time (Bjørk et al., 2012). Currently yearly observations of the terminus position are available (Murray et al., 2015; Joughin et al., 2017) for the entire ice sheet, including via NASA and ESA. Regional subsets of glaciers have more frequent observations of terminus position, up to twice-monthly in some regions (e.g., Seale et al., 2011; Carr et al., 2015; Murray et al., 2015; Catania et al., 2018), but these records are dispersed among individual researchers or archives. GrIOOS will need to build on these existing efforts to establish a consistent and complete terminus position data stream.

\section{Surface Elevation}

From 1993 to 2003 surface elevation data have been acquired over the GrIS to understand glacier dynamic evolution in response to climate forcing with NASA's airborne laser altimeter (Krabill et al., 1999; Abdalati et al., 2002). From 2003 to 2009 NASA's ICESat mission provided laser altimetry data over the entire ice sheet and altimetry is now being continued through to the recent launch of ICESat-2. In the interim, NASA's Operation Icebridge has provided continuous elevation data ${ }^{9}$. Combined, these data are used to constrain modeled estimates of elevation change for the entire ice sheet over the entire duration that observations are available (Csatho et al., 2014). In addition to laser altimetry, surface elevation change observations from additional airborne and satellite missions have enabled the creation of digital elevation models (DEMs) for the GrIS. In some cases these DEMs have been created from historical air photos acquired in stereo to produce elevation data extending back to the late 1970s (Korsgaard et al., 2016). Additional DEMs have been created from the commercial vendor DigitalGlobe through its provision of high-resolution optical imagery of the polar regions over the launch of six WorldView spacecraft (Shean et al., 2016). DigitalGlobe coverage began in 2009 with sporadic coverage until 2012, with the periphery of the GrIS covered with stereo-pairs every year since. Data are currently processed and made available through the Polar Geospatial Center (Porter et al., 2018). The Polar Geospatial Center also serves time-stamped ArcticDEM strips. A useful summary of the last 25 years of surface elevation change is given by Sørensen et al. (2018) based on ESA Greenland data from ERS, ENVISAT and Cryosat-2.

\section{Surface Runoff and Subglacial Discharge}

The estimate of ice sheet surface mass budget and runoff, routed through individual glacier catchments, is critical for quantifying the spatio-temporal distribution of meltwater-driven terminus melt as well as freshwater discharge and the timing and magnitude of biogeochemical transports. However, ice sheet SMB and runoff continues to be poorly validated at the outlet glacier scale because of the difficulties involved in measuring

\footnotetext{
${ }^{9}$ icebridge.gsfc.nasa.gov
} 
subglacial discharge. Observations of SMB are made at the locations of automatic weather stations (van As et al., 2011) and from snowpits and shallow firn cores on e.g., repeat transects (Machguth et al., 2016). This data has been key to evaluating SMB and runoff derived from regional climate models (e.g., Langen et al., 2017) that has been used in the past for driving ice sheet and coupled ocean-ice sheet models (e.g., Slater et al., 2015). However, while these observations will continue to be important the onice environment at outlet glaciers is typically not conducive or indeed accessible to the kind of on-ice instrumentation required to measure surface accumulation, melt and runoff particularly over long time periods.

Various researchers have discretized time-series surface mass balance data (described below) into regional or individual glacier catchments using surface and bed topography of the ice sheet to quantify how much runoff drains into a particular catchment (e.g., Carroll et al., 2016; Jackson et al., 2017). The timing and delivery location of meltwater runoff to the terminus has been cross-checked with identification of visible sediment plumes on the fjord surface from satellite images and the formation of terminus embayments where enhanced terminus change occurs as a result of significant melt at depth (Fried et al., 2015). However, not all subglacial conduits will deliver sedimentladen water that reaches the fjord surface (Carroll et al., 2016). Empirically most $(\sim 80 \%)$ of the runoff transits through a small number of channels that have the largest impact on terminus retreat (Fried et al., 2018). Validation of runoff has occurred in regions with land-terminating ice, for example in the Watson River catchment in southwest Greenland (Smith et al., 2017), with good agreement between proglacial discharge and surface melt estimated via regional climate model (van As et al., 2017).

\section{Atmospheric Measurements Weather Station Data}

Weather observations in Greenland are perhaps some of the longest time-series and most mature climate information available, with DMI and Asiaq (Asiaq Greenland Survey) maintaining a network of meteorological stations around the margins of the GrIS (and at Summit Station), in some cases back to 1784 . These data are freely available to download from the DMI homepage and are fully quality controlled (a new open data policy at DMI includes the development of a data portal that will considerably simplify the process of accessing existing data and other data or products, such as forecast model output that is not currently routinely available). As a national weather institute, DMI stations conform to World Meteorological Organization standards in terms of siting and sensors. There are also radiosondes operated at two sites on the coast of Greenland giving atmospheric profiles. PROMICE is a Danish governmentfunded monitoring network with the goal of providing consistent long-term observations to calculate mass loss by the energy budget method using weather station observations (precipitation, surface temperature, radiation, humidity, wind speed, and direction) from a network of sites around the GrIS (van As et al., $2011,2017)$. This network consists of $>23$ automated weather stations distributed in the ablation zone around the GrIS since 2007. The network has large spatial coverage and is expected to be maintained long-term for monitoring mass loss of the ice sheet. The main component of PROMICE is the free online database that includes historical mass balance data, documentation of recent change, and outreach efforts. PROMICE is complemented by GC-NET, a network of AWS in the upper accumulation zone of the ice sheet operated by University of Colorado (e.g., Steffen and Box, 2001).

\section{Dynamical and Statistical Reconstructions}

Several methods are used to reconstruct the surface atmospheric state above the GrIS, from which surface mass balance may be derived ice sheet-wide. Global atmospheric reanalysis products assimilate satellite and in-situ data into atmospheric weather models to provide best-possible analyses of the state of the atmosphere, including the GrIS. Examples of such products are ECMWF's ERA-Interim (Dee et al., 2011), ERA-20C (Poli et al., 2016), or NASA's MERRA-2 (Gelaro et al., 2017); for a more complete list, see Lindsay et al. (2014). Because of the limited spatial resolving power of global reanalyses (order of $30 \mathrm{~km}$ over Greenland), limited area (i.e., regional) atmospheric or climate models have been developed that use lateral boundary conditions from global reanalyses. Limited area climate models provide hindcast simulations of the regional domain at much higher spatial resolution (order of $10 \mathrm{~km}$ ) that are calibrated or validated using Greenlandic weather observations, and compute ice sheetwide surface mass balance. Three major such efforts are the Modèle Atmosphérique Régional (MAR; Fettweis et al., 2017) ${ }^{10}$, the Regional Atmospheric Climate Model, version 2 (RACMO2; Noël et al., 2018) ${ }^{11}$, and the High-Resolution Limited Area Model, version 5 (HIRLAM5; Langen et al., 2015; Mottram et al., 2017a). Finally, to obtain very high-resolution (order of $1 \mathrm{~km}$ ) estimates of the surface atmospheric state and implied surface mass balance, statistical downscaling methods have been developed (e.g., Noël et al., 2016; Wilton et al., 2017). In these limited area models, the freshwater discharge from the ice sheet (called runoff) is provided as a time-series across the entire region.

A new Arctic regional reanalysis for 1998-2020, at the extremely high resolution of $2.5 \mathrm{~km}$, will also go into production in 2019-2021 with a specific aim of resolving Greenland's complex topography including fjords. Part of the Copernicus regional reanalysis project and run by the Norwegian, Danish, Swedish, Finnish and Icelandic Meteorological Institutes together with Meteofrance, this represents a major step forward in regional atmospheric data for the Arctic and will provide exceptionally high quality data. The reanalysis is built on the HARMONIE numerical weather prediction system (Bengtsson et al., 2017) used operationally in Europe, Greenland and Iceland and verified to be of very high quality over the ice sheet including in the fjords (Mottram et al., 2017b).

\section{Other Integrated Networks \\ Greenland Ecosystem Monitoring (GEM)}

Greenland ecosystem monitoring is an integrated monitoring and long-term research program on ecosystems and climate

\footnotetext{
${ }^{10}$ www.cryocity.org/mar-explorer.html

${ }^{11}$ www.projects.science.uu.nl/iceclimate/models/racmo.php
} 
change effects and feedbacks in the Arctic. Since 1994, the program has established a coherent and integrated understanding of the ecosystem functioning in a highly variable climate, which is based upon a comprehensive, long-term inter-disciplinary data collection carried out by Greenlandic and Danish monitoring and research institutions, primarily at the three main field stations: Nuuk in low arctic West Greenland, Qeqertarsuaq in Disko Bay, and Zackenberg in high arctic Northeast Greenland ${ }^{12}$. GEM sites also have significant fjord measurements that could be useful in this context.

\section{Greenland Integrated Observing System (GIOS)}

Greenland Integrated Observing System is a broad institutional collaboration between research institutions to integrate and collaborate on long-term measuring programs in Greenland. This has so far resulted in the Arctic gateway, Isaaffik homepage ${ }^{13}$ where all measuring programs and projects in Greenland are visible. NSF has recently added their project and activities also. A combined GIOS program is under development and discussions on how to make this a part of an Arctic science hub in Greenland is currently taking place.

\section{DMI Winter Observatory and Ongoing NW Greenland Observations}

DMI runs an ongoing (started in 2011) winter monitoring program based in Qaanaaq in northwest Greenland. The observational effort relies on the engagement of and cooperation with local hunters and traditional knowledge has been taken into account in the design and timing of components, which include:

1 In December, a sled team instruments a section across the fjord with ice tethered ocean moorings, ice mass balance buoys, and an on-ice automated weather station. Instruments log data until June and are maintained by local hunters.

2 In March, when conditions are favorable for sled journeys, a week long oceanographic CTD campaign is conducted seaward from the glaciers at the head of the fjord.

In addition, DMI operates a manned station in Qaanaaq that offers logistic support for the activities in the fjord, including recent Japanese research activities at Bowdoin Glacier (Sugiyama et al., 2015).

\section{Baffin Bay Observing System}

Canada leads a new Canada Excellence Research Chair program that will focus efforts on fresh water-marine coupling in Baffin Bay. The program is designed as phase one to a Baffin Bay Observing System (Rysgaard and BBOS Committee, 2017) that is being developed as a parallel effort to GrIOOS. The Baffin Bay Observing System is a unique 'big science' idea building on a strong collaboration between national and international Universities, Inuit organizations, communities on both sides of Baffin Bay, government ministries and agencies, defense, shipping and marine based companies,

\footnotetext{
${ }^{12} \mathrm{http}: / / \mathrm{g}-\mathrm{e}-\mathrm{m} . \mathrm{dk}$

${ }^{13}$ https://www.isaaffik.org
}

various technology providers, industry, coastal and offshore fisheries and colleges, all focused around a single collaborative world-class-bay-wide observatory ${ }^{14}$. It is being initiated in the northern part of Baffin Bay through strong collaboration between the Arctic Science Partnership ${ }^{15}$ and the Pikialasorsuaq Commission ${ }^{16}$.

The Canadian program will develop knowledge, tools, and models that will improve understanding of how freshwater fluxes (solid and liquid phase) from glaciers, ice caps and the GrIS, are delivered to the adjacent marine system and what impacts this freshwater has on physical, biological, and geochemical processes in the marine system. The geographic focus of the work will be Baffin Bay, with investigations of both Canadian and Greenlandic glaciers exporting freshwater to the Bay. Process studies will also include in situ studies of the North East Greenland Ice Stream, Petermann Fjord, Ellesmere and Baffin Island Glaciers, and ice fluxes exiting the west side of the GrIS into Melville Bay. Discussions have begun with how to link the field stations sites of the CERC program to the station sites of GrIOOS and how to engage the CERC research themes in this international collaboration. An Inuit led community based monitoring program will be developed through a unique partnership with the Inuit Circumpolar Council focused on the Pikialasorsuaq, near the North Open Water Polynya area of northern Baffin Bay. The northern end of Baffin Bay is a key area for both renewable and non-renewable resources, and an excellent candidate for an Inuit-managed marine management area.

\section{GNET: Greenland Network of GPS Stations}

GNET (Greenland GPS Network) - a network of GPS stations, located on the bedrock, initially deployed and maintained by funding from NSF - is now owned and operated by the Danish Technical University under contract to Ministry of Energy, Climate and Utilities. The stations have proved to be successful in quantifying precise crustal movements related to changes in ice load and, as such, are therefore a valuable source of validation of both local and ice sheet wide mass changes.

\section{ORGANIZATION/FRAMEWORK}

It is envisioned that GrIOOS will be achieved through the coordination of long-term measurements at multiple sites collected by different institutions and nations. It can build on existing efforts to build long-term records of certain oceanic, atmospheric and/or glaciological parameters at certain sites which have, so far, been occurring in isolation one from the another. By identifying the measurements needed at each site, and describing the data collection and processing protocols GrIOOS will provide a framework that enables coordination amongst the different efforts and a structure for making the data available to the broader scientific community.

\footnotetext{
${ }^{14} \mathrm{http}: / /$ www.researchgate.net/project/Baffin-Bay-Observatory-System

${ }^{15} \mathrm{http}: / /$ www.asp-net.org

${ }^{16}$ http://pikialasorsuaq.org/en/
} 


\section{Overall Governance Structure}

The international and multidisciplinary nature of GrIOOS calls for a governance structure that serves several overarching purposes: (i) efficient pooling and optimal use of the limited observational assets to fulfill the science goals; (ii) efficient communication, coordination, and collaboration across a heterogeneously structured international and multidisciplinary science team, funding agency landscape, and organizational/government representation; and (iii) successful and sustained execution of GrIOOS. Similar challenges have been successfully tackled, or are being addressed by international programs, such as the Southern Ocean Observing System ${ }^{17}$ the Integrated Atlantic Ocean Observing Systems ${ }^{18}$ or the Deep Ocean Observing Strategy ${ }^{19}$ (see Levin et al., 2019). To achieve these goals, we propose the establishment of a governance structure as follows:

(i) An Executive Committee oversees the proper execution and efficient functioning of GrIOOS at an operational level. The Executive Committee also directs a Project Management Panel, which is responsible for, and responsive to, day-today operational aspects.

(ii) A Scientific Steering Committee ensures that GrIOOS is working toward achieving the science goals.

(iii) Working with the Executive and Scientific Steering Committees are several panels and boards:

- An External Advisory Board - to oversee GrIOOS, make recommendations where needed;

- A Data Management Panel - its role is to implement and oversee an ambitious data management plan that follows FAIR principles (see Data Protocol and Management).

- A Community Engagement and Outreach Panel - its role is to engage scientific, end user, stakeholder, and local communities in various aspects of the program (see End Users);

- A Liaison team of international/interagency members, working on matters concerning international and/or interagency (see International/Interagency Liaisons).

\section{Data Protocol and Management}

A vision for GrIOOS is to implement the principle of FAIR data (Wilkinson et al., 2016) within the complexities of a multidisciplinary international program. In the following we list some of these tasks and provide further comments, where applicable.

Pre-deployment phase: Much can be gained in terms of efficient data management by developing a comprehensive sensor information system, which consists of creating and managing metadata of devices, sensors, and variables ahead of their deployment. Likewise, data quality control policies and best practice procedures should be established. Finally, data sharing policies and procedures in line with the FAIR principles should be formulated and agreed upon early on in the project.

\footnotetext{
${ }^{17} \mathrm{http} / / /$ www.soos.aq

${ }^{18} \mathrm{http}: / /$ atlanticblueprint.net

${ }^{19} \mathrm{http}: / /$ www.deepoceanobserving.org
}

Post-deployment phase: An infrastructure is required for data acquisition and transmission to an archiving facility that can further process the data. As with most observing networks, the value of a network is augmented by serving multiple communities and stakeholders (but without compromising its primary purpose). Real time data dissemination should be considered where feasible for variables and/or measurement platforms; primary applications of real time dissemination are ingestion of these observations in forecast models, as well as operational and local community support. An initial goal of the GrIOOS executive committee will be to identify mature variables (and corresponding platforms) for real time dissemination. Collaboration with the operational branch of the Joint Technical Commission for Oceanography and Marine Meteorology of the World Meteorological Organization and UNESCO's Intergovernmental Oceanographic Commission will be explored to enable real time data transmission.

After transmission, metadata tagging should be completed (where needed) and the data set curated. It should be ensured that the data are searchable and accessible using standard metadata formats that are supported by common protocols, web services, and search engines (Google, DataCite, WorldCat, EOSDIS).

In considering data storage, archiving, and server infrastructure, GrIOOS should establish the roles of existing data portals that are recognized by the World Data System (major portals in the U.S. are http://arcticdata.io and http://nsidc.org; in Europe: http://pangaea.de and http://ices.dk). Interoperability between them should be assessed or invigorated. Finally, GrIOOS should address how to ensure the longevity and sustainability of the data infrastructure beyond the conventional life cycle (from measurement/creation to post-analysis $\operatorname{archiving}^{20}$ ) of the data sets.

Several frameworks exist to date that have implemented (or work toward implementing) some of the tasks listed above. The U.S. National Science Foundation's Arctic Observing Network program requires data to be immediately available. PROMICE demonstrates that near-real time data are important, valued, and successful. Quick access to data is key either centralized or via a standardized metadata structure that enables data access in the cloud.

A well-developed data infrastructure that succeeds at data integration (i.e., crossing of ice-ocean-atmosphere divide as well as the synthesis of remote-sensing and in situ observations) has the potential of creating transformative science through simultaneous accessibility of diverse and heterogeneous, spatiotemporally tagged geophysical parameters. In such a way, the disciplinary "sparse data" problem may turn into a multidisciplinary "big data" opportunity that lends itself to emerging tools of big data analytics or coupled Earth system data assimilation. Another important aspect of the data infrastructure to be developed is the evaluation process to measure the success and impact of the observing system itself. Such metrics would include data portal access and usage, as well as recording who is using the observations (e.g., academia, industry, other stakeholders).

\footnotetext{
${ }^{20}$ https://www.dataone.org/data-life-cycle
} 


\section{End Users}

The data provided by GrIOOS targets a diverse array of end-users from the governmental, non-profit, academic, industrial, and local communities. These observations are needed to improve ice, ocean, atmospheric and earth system models in which the processes governing glacier/ocean exchanges are currently absent or represented through parameterizations that have not been validated by field measurements. GrIOOS data can support improved parameter development. Additional identified users include local Greenlandic and Canadian communities searching for information on real-time ocean temperatures, sea ice coverage, nutrient levels, or productivity in their nearby fjords, and national governments searching for information on iceberg hazards, long-term trends in water properties, or glacier melt predictions that might drive local hydroelectricity. Other end-users are the international iceberg hazard community, which includes the International Ice Patrol (Murphy and Cass, 2012) and Canadian efforts (Crawford et al., 2018), as well as the marine mammal community (Roquet et al., 2017; Treasure et al., 2017). In addition to governmental entities, GrIOOS data will serve local and international fisheries, and local tourism industries that rely on both the ice and ocean environment.

To make GrIOOS data available to these communities, and gather feedback on future developments, GrIOOS will hold inclusive annual meetings. Beyond these meetings, GrIOOS will maintain an active program website and data platform that will be a natural intellectual gathering location for these groups to exchange data and ideas. As needed GrIOOS will hold open workshops on data and uses, as well as update the program website with community tools, tutorials, and wikis; definition of metrics of progress; regular communication of progress; and requests for input at public forums. These activities will be overseen by the Community Engagement and Outreach Panel.

On the outreach side, one prime example is the world heritage site Ilulissat Icefjord where significant increase in tourism is expected to view the impressive icebergs and fjord system and where a new museum with a significant scientific content is currently under construction. GrIOOS and its community can leverage the high visibility of Greenland in outreach and public education efforts across the globe. The experience of using striking visualizations of scientific data to generate awareness has been successfully demonstrated on the polar portal website $e^{21}$ where a broad array of mostly near real-time data from models and observations in Greenland as well as the wider Arctic receives around 180,000 page impressions per year. The outreach potential of the polar portal is demonstrated by a teacherled initiative currently underway and funded by the Danish government to develop teaching resources based on polar portal datasets for Danish and Greenlandic high school students. These resources will be made publically accessible via the site and will be translated into English.

Within the outlined governance structure (see Overall Governance Structure), community connections will ensure that all interested groups are involved in project development and that outputs are widely used. These groups include the modeling

\footnotetext{
${ }^{21}$ polarportal.dk
}

community (e.g., the modeling intercomparison project groups), researchers working on surface processes at the ice sheet edge (e.g., the Community Surface Dynamics Modeling Systems community), groups conducting process studies on ice-ocean interactions and fjord environments, biologists and ecologists focused on Arctic flora and fauna, sedimentologists, nutrient flux and biogeochemistry experts, industry members, local communities and hunters, and regional governments.

\section{International/Interagency Liaisons}

Major roles of the Liaison team are to maintain efficient communications between agencies and foundations at the national and international level.

- In Europe, the team will establish primary liaisons with institutions and organizations in Greenland (including its government) and Denmark, in particular Asiaq, GINR, GEUS, DMI, Danish Technical University, Aarhus University, Københavns University, PROMICE, and GEM; see also section "Other Integrated Networks." Strong links will also be established with institutions, organizations, and governments of other countries that conduct significant research in Greenland, such as Norway, United Kingdom, Germany, Sweden, and Switzerland.

- In the U.S., lines of communications will be established with both inter-agency organizations, such as the Interagency Arctic Research Policy Committee (IARPC), Interagency Ocean Observation Committee (IOOC), US CLIVAR, Arctic Research Commission of the United States (USARC), Arctic Research Consortium of the United States (ARCUS), as well as directly with major funding agencies (e.g., NASA, NSF, USGS).

- In Canada, one primary liaison will be through the University of Manitoba. Government involvement will be sought through Fisheries and Oceans Canada and Environment and Climate Change Canada, with particular reference to shared jurisdiction of Baffin Bay. Another important link is with the Inuit Circumpolar Council, with particular connections to similar councils in Greenland and Canada through the Pikiialasorsuaq Partnership in Baffin Bay.

- Internationally, we will strengthen or establish links to international organizations or programs that are engaged in GrIOOS related themes, e.g., CliC, International CLIVAR, GEOTRACES, Arctic Council. In addition, we will seek to include efforts by groups in all other countries that are engaged in GrIOOS related efforts.

\section{MOVING FORWARD}

The case for an integrated GrIOOS is clear: Greenland's fjords and outlet glacier regions are key connections between the open ocean and the interior ice sheet that are not currently monitored systematically. We plan to establish a GrIOOS network to collect long-term data on essential variables from key ice sheet-ocean locations that cover a range of 
glacier/fjord configurations, different oceanic basins, and climatic regimes. Essential measurements to be collected at these sites include oceanic (temperature, salinity, pressure, sea ice cover, iceberg production and distribution, and basic biogeochemical parameters in the fjord and nearby shelf), glaciological (ice velocity, surface elevation and ice thickness, terminus position, and subglacial runoff) and atmospheric (wind, temperature, precipitation, and radiation). Bathymetry and bedrock are foundational data sets needed for any GrIOOS site. Together, these data provide the information needed to understand and project ice sheet-ocean behavior and change and its impact on the ocean.

Over the next few years, the continued development and maintenance of GrIOOS will require close international collaboration. GrIOOS' implementation will need to be coordinated amongst different countries, paying close attention to minimizing costs and optimizing shared logistics. Several glacier/fjord locations that have ongoing observational programs may be designated GrIOOS sites, and a protocol for the establishment and endorsement of future sites will be formalized through our governance structure. Data processing protocols and data sharing practices will also be formalized. Quick, open, and centralized access to data is critical to all GrIOOS users.

GrIOOS will represent a step-change in our observational capacity around the GrIS and will drastically improve our

\section{REFERENCES}

Abdalati, W., Krabill, W., Frederick, E., Manizade, S., Martin, C., Sonntag, J., et al. (2002). Airborne laser altimetry mapping of the Greenland ice sheet: application to mass balance assessment. J. Geodynam. 34, 391-403. doi: 10.1016/S02643707(02)00048-0

Ahlstrøm, A. P., Andersen, S. B., Andersen, M. L., Machguth, H., Nick, F. M., Joughin, I., et al. (2013). Seasonal velocities of eight major marine-terminating outlet glaciers of the Greenland ice sheet from continuous in situ GPS instruments. Earth Syst. Sci. Data 5, 277-287. doi: 10.5194/essd-5-277-2013

Andresen, C. S., Straneo, F., Ribergaard, M. H., Bjørk, A. A., Andersen, T. J., Kuijpers, A., et al. (2012). Rapid response of helheim glacier in Greenland to climate variability over the past century. Nat. Geosci. 5:37. doi: 10.1038/ ngeo1349

Arrigo, K. R., Dijken, G. L., Castelao, R. M., Luo, H., Rennermalm, A. K., Tedesco, M., et al. (2017). Melting glaciers stimulate large summer phytoplankton blooms in southwest Greenland waters. Geophys. Res. Lett. 44, 6278-6285. doi: 10.1002/2017GL073583

Bamber, J., van den Broeke, M., Ettema, J., Lenaerts, J., and Rignot, E. (2012). Recent large increases in freshwater fluxes from Greenland in the North Atlantic. Geophys. Res. Lett. 39:L19501. doi: 10.1029/2012GL0 52552

Bamber, J. L., Tedstone, A. J., King, M. D., Howat, I. M., Enderlin, E. M., van den Broeke, M. R., et al. (2018). Land ice freshwater budget of the Arctic and North Atlantic Oceans: 1. data, methods, and results. J. Geophys. Res. Oceans 123, 1827-1837. doi: 10.1002/2017JC013605

Barber, D. G. (2005). Microwave remote sensing, sea ice and arctic climate. Phys. Can. 8, 105-111.

Barber, D. G., and Massom, R. A. (2007). "The role of sea ice in arctic and antarctic polynyas," in Polynyas: Windows to the World, Vol. 74, eds W. O. Smith and D. G. Barber (Amsterdam: Elsevier), 1-54. doi: 10.1016/S0422-9894(06)74001-6

Barber, D. G., McCullough, G., Babb, D. G., Komarov, A. S., Candlish, L. M., Lukovich, J. V., et al. (2014). Climate change and ice hazards in the Beaufort Sea. Elem. Sci. Anth. 2:000025. doi: 10.12952/journal.elementa.000025 understanding of mechanisms that influence sea level rise, increased freshwater flux to the North Atlantic Ocean, and local and regional ecosystem effects from a changing ice sheet. A successful GrIOOS will satisfy the needs of many distinct endusers, from the scientific community of global climate modelers and ice-ocean researchers to local and regional government entities around Greenland.

\section{DATA AVAILABILITY}

No datasets were generated or analyzed for this study.

\section{AUTHOR CONTRIBUTIONS}

FS, DS, LS, GC, PH, and TM conceived and wrote the paper with contributions from MC, KL, DB, SR, RM, SO, $\mathrm{MH}$, and LM.

\section{FUNDING}

FS, DS, PH, TM, and GC acknowledge funding from NSF EarthCube's GRISO Research Coordination Network, ICER - 1743687.

Bartholomaus, T. C., Larsen, C. F., and O’Neel, S. (2013). Does calving matter? Evidence for significant submarine melt. Earth Planet. Sci. Lett. 380, 21-30. doi: 10.1016/j.epsl.2013.08.014

Beaird, N., Straneo, F., and Jenkins, W. (2015). Spreading of Greenland meltwaters in the ocean revealed by noble gases. Geophys. Res. Lett. 42, 7705-7713. doi: 10.1002/2015GL065003

Beaird, N., Straneo, F., and Jenkins, W. (2017). Characteristics of meltwater export from Jakobshavn Isbræ and Ilulissat Icefjord. Anna. Glaciol. 64, 107-117. doi: 10.1017/aog.2017.19

Beaird, N. L., Straneo, F., and Jenkins, W. (2018). Export of strongly diluted Greenland meltwater from a major glacial fjord. Geophys. Res. Lett. 45, 41634170. doi: 10.1029/2018GL077000

Bendtsen, J., Mortensen, J., Lennert, K., and Rysgaard, S. (2015). Heat sources for ice melt in a west Greenland tidewater outlet glacier fjord: the role of subglacial freshwater discharge. Geophys. Res. Lett. 42, 4089-4095. doi: 10.1002/ 2015GL063846

Bengtsson, L., Andrae, U., Aspelien, T., Batrak, Y., Calvo, J., de Rooy, W., et al. (2017). The HARMONIE-AROME model configuration in the ALADINHIRLAM NWP system. Mon. Weather Rev. 145, 1919-1935. doi: 10.1175/ MWR-D-16-0417.1

Berthelsen, T. (2014). Coastal Fisheries in Greenland. Available at: http://www.coastalfisheries.net/wp-content/uploads/2013/06/Coastal-fishingin-Greenland.pdf

Bevis, M., Bevis, M., Wahr, J., Khan, S. A., Madsen, F. B., Brown, A., et al. (2012). Bedrock displacements in Greenland manifest ice mass variations, climate cycles and climate change. Proc. Natl. Acad. Sci. U.S.A. 109, 11944-11948. doi: 10.1073/pnas.1204664109

Bjørk, A. A., Kjær, K. H., Korsgaard, N. J., Khan, S. A., Kjeldsen, K. K., Andresen, C. S., et al. (2012). An aerial view of 80 years of climate-related glacier fluctuations in southeast Greenland. Nat. Geosci. 5:427. doi: 10.1038/ngeo1481

Böning, C. W., Behrens, E., Biastoch, A., Getzlaff, K., and Bamber, J. L. (2016). Emerging impact of Greenland meltwater on deepwater formation in the North Atlantic Ocean. Nat. Geosci. 9, 523-527. doi: 10.1038/ngeo2740

Boone, W., Rysgaard, S., Kirillov, S., Dmitrenko, I., Bendtsen, J., Mortensen, J., et al. (2017). Circulation and fjord-shelf exchange during the ice covered period in 
Young Sound-Tyrolerfjord, NE-Greenland $\left(74^{\circ} \mathrm{N}\right)$. Estuar. Coast. Shelf Sci. 194, 205-216. doi: 10.1016/j.ecss.2017.06.021

Buus-Hinkler, J., Qvistgaard, K., and Krane, K. A. H. (2014). "Iceberg number density - reaching a full picture of the Greenland waters," in Proceedings of the 2014 IEEE Geoscience and Remote Sensing Symposium. Presented at the IGARSS 2014 - 2014 IEEE International Geoscience and Remote Sensing Symposium, (Quebec City: IEEE), 270-273. doi: 10.1109/IGARSS.2014.6946409

Cape, M. R., Straneo, F., Beaird, N., Bundy, R. M., and Charette, M. A. (2019). Nutrient release to oceans from buoyancy-driven upwelling at Greenland tidewater glaciers. Nat. Geosci. 12, 34-39. doi: 10.1038/s41561-018-0268-4

Carr, J. R., Vieli, A., Stokes, C. R., Jamieson, S. S. R., Palmer, S. J., Christoffersen, P., et al. (2015). Basal topographic controls on rapid retreat of Humboldt Glacier, northern Greenland. J. Glaciol. 61, 137-150. doi: 10.3189/2015JoG14J128

Carroll, D., Sutherland, D. A., Hudson, B., Moon, T., Catania, G. A., Shroyer, E. L., et al. (2016). The impact of glacier geometry on meltwater plume structure and submarine melt in Greenland fjords. Geophys. Res. Lett. 43, 9739-9748. doi: 10.1002/2016GL070170

Carroll, D., Sutherland, D. A., Shroyer, E. L., Nash, J. D., Catania, G. A., and Stearns, L. A. (2015). Modeling turbulent subglacial meltwater plumes: implications for fjord-scale buoyancy-driven circulation. J. Phys. Oceanogr. 45, 2169-2185. doi: 10.1175/JPO-D-15-0033.1

Carroll, D., Sutherland, D. A., Shroyer, E. L., Nash, J. D., Catania, G. A., and Stearns, L. A. (2017). Subglacial discharge-driven renewal of tidewater glacier fjords. J. Geophys. Res. Oceans 122, 6611-6629. doi: 10.1002/2017JC012962

Catania, G. A., Stearns, L. A., Sutherland, D. A., Fried, M. J., Bartholomaus, T. C., Morlighem, M., et al. (2018). Geometric controls on tidewater glacier retreat in central Western Greenland. J. Geophys. Res. Earth Surf. 123, 2024-2038. doi: 10.1029/2017JF004499

Chambers, D. P., Cazenave, A., Champollion, N., Dieng, H., Llovel, W., Forsberg, R., et al. (2017). Evaluation of the global mean sea level budget between 1993 and 2014. Surv. Geophys. 38, 309-327. doi: 10.1007/s10712-0169381-3

Chauché, N., Hubbard, A., Gascard, J. C., Box, J. E., Bates, R., Koppes, M., et al. (2014). Ice-ocean interaction and calving front morphology at two west Greenland tidewater outlet glaciers. Cryosphere 8, 1457-1468. doi: 10.5194/tc8-1457-2014

Cipollini, P., Calafat, F. M., Jevrejeva, S., Melet, A., and Prandi, P. (2016). Monitoring sea level in the coastal zone with satellite altimetry and tide gauges. Surv. Geophys. 38, 33-57. doi: 10.1007/s10712-016-9392-0

Claustre, H., Bishop, J., Boss, E., Stewart, B., Berthon, J.-F., Coatanoan, C., et al. (2010). "Bio-optical profiling floats as new observational tools for biogeochemical and ecosystem studies," in Proceedings of the "OceanObs'09: Sustained Ocean Observations and Information for Society" Conference, eds J. Hall, D. E. Harrison, and D. Stammer, Venice, 21-25. doi: 10.5270/OceanObs09. cwp. 17

Cowton, T., Slater, D., Sole, A., Goldberg, D., and Nienow, P. (2015). Modeling the impact of glacial runoff on fjord circulation and submarine melt rate using a new subgrid-scale parameterization for glacial plumes. J. Geophys. Res. Oceans 120, 796-812. doi: 10.1002/2014JC010324

Crawford, A., Crocker, G., Mueller, D., Desjardins, L., Saper, R., and Carrieres, T. (2018). The canadian ice island drift, deterioration and detection (CI2D3) database. J. Glaciol. 64, 517-521. doi: 10.1017/jog.2018.36

Csatho, B. M., Schenk, A. F., van der Veen, C. J., Babonis, G., Duncan, K., Rezvanbehbahani, S. R., et al. (2014). Laser altimetry reveals complex pattern of Greenland Ice Sheet dynamics. Proc. Natl. Acad. Sci. U.S.A. 111, 18478-18483. doi: 10.1073/pnas.1411680112

Curry, B., Lee, C. M., Petrie, B., Moritz, R. E., and Kwok, R. (2014). Multiyear volume, liquid freshwater, and sea ice transports through Davis Strait, 2004-10. J. Phys. Oceanogr. 44, 1244-1266. doi: 10.1175/JPO-D-13-0177.1

de Steur, L., Hansen, E., Mauritzen, C., Beszczynska-Moeller, A., and Fahrbach, E. (2014). Impact of Recirculation on the East Greenland Current: results from moored current meter measurements between 1997 and 2009. Deep Sea Res. Part I Oceanogr. Res. Pap. 92, 26-40. doi: 10.1016/j.dsr.2014.05.018

Dee, D. P., Uppala, S. M., Simmons, A. J., Berrisford, P., Poli, P., Kobayashi, S., et al. (2011). The ERA-Interim reanalysis: configuration and performance of the data assimilation system. Quart. J. R. Meteorol. Soc. 137, 553-597. doi: $10.1002 / q j .828$

Dieng, H. B., Cazenave, A., Meyssignac, B., and Ablain, M. (2017). New estimate of the current rate of sea level rise from a sea level budget approach. Geophys. Res. Lett. 44, 3744-3751. doi: 10.1002/2017GL073308
Enderlin, E. M., Hamilton, G. S., Straneo, F., and Sutherland, D. A. (2016). Iceberg meltwater fluxes dominate the freshwater budget in Greenland's icebergcongested glacial fjords. Geophys. Res. Lett. 43, 11287-11294. doi: 10.1002/ 2016GL070718

Enderlin, E. M., Howat, I. M., Jeong, S., Noh, M. J., Angelen, J. H., and Broeke, M. R. (2014). An improved mass budget for the Greenland ice sheet. Geophys. Res. Lett. 41, 866-872. doi: 10.1002/(ISSN)1944-8007

Fenty, I., Willis, J. K., Khazendar, A., Dinardo, S., Forsberg, R., Fukumori, I., et al. (2016). Oceans melting greenland: early results from NASA's ocean-ice mission in Greenland. Oceanography 29, 72-83. doi: 10.5670/oceanog.2016.100

Fettweis, X., Box, J. E., Agosta, C., Amory, C., Kittel, C., Lang, C., et al. (2017). Reconstructions of the 1900-2015 Greenland ice sheet surface mass balance using the regional climate MAR model. Cryosphere 11, 1015-1033. doi: 10.5194/ tc-11-1015-2017

Fransson, A., Chierici, M., Nomura, D., Granskog, M. A., Kristiansen, S., Martma, T., et al. (2015). Effect of glacial drainage water on the $\mathrm{CO} 2$ system and ocean acidification state in an Arctic tidewater-glacier fjord during two contrasting years. J. Geophys. Res. Oceans 120, 2413-2429. doi: 10.1002/ 2014JC010320

Fraser, N. J., and Inall, M. E. (2018). Influence of barrier wind forcing on the heat delivery toward the Greenland Ice Sheet. J. Geophys Res. 123, 2513-2538. doi: 10.1002/2017JC013464

Fried, M. J., Catania, G. A., Bartholomaus, T. C., Duncan, D., Davis, M., Stearns, L. A., et al. (2015). Distributed subglacial discharge drives significant submarine melt at a Greenland tidewater glacier. Geophys. Res. Lett. 42, 9328-9336. doi: 10.1002/2015GL065806

Fried, M. J., Catania, G. A., Bartholomaus, T. C., Sutherland, D. A., Stearns, L. A., Shroyer, E. L., et al. (2018). Reconciling drivers of seasonal terminus advance and retreat at thirteen central west Greenland tidewater glaciers. J. Geophys. Res. Earth Surf. 123, 1590-1607. doi: 10.1029/2018JF004628

GCRC (2015). Greenland Climate Research Center Strategy Document. Available at: https://gcrc.gl/wp-content/uploads/2018/04/GCRC-strategi-2015-20.pdf.

Gelaro, R., McCarty, W., Suarez, M. J., Todling, R., Molod, A., Takacs, L., et al. (2017). The modern-era retrospective analysis for research and applications, version 2 (MERRA-2). J. Clim. 30, 5419-5454. doi: 10.1175/JCLI-D- 16-0758.1

Gladish, C. V., Holland, D. M., Rosing-Asvid, A., Behrens, J. W., and Boje, J. (2015). Oceanic boundary conditions for jakobshavn glacier. Part I: variability and renewal of ilulissat icefjord waters, 2001-14. J. Phys. Oceanogr. 45, 3-32. doi: 10.1175/JPO-D-14-0044.1

Grist, J. P., Josey, S. A., Boehme, L., Meredith, M. P., Laidre, K. L., Heide-Jørgensen, M. P., et al. (2014). Seasonal variability of the warm Atlantic Water layer in the vicinity of the Greenland shelf break. Geophys. Res. Lett. 41, 8530-8537. doi: 10.1002/2014GL062051

Gruber, N., Doney, S., Emerson, S., Gilbert, D., Kobayashi, T., Körtzinger, A., et al. (2010). "Adding oxygen to Argo: developing a global in-situ observatory for ocean deoxygenation and biogeochemistry," in Proceedings of the "OceanObs'09: Sustained Ocean Observations and Information for Society" Conference, eds J. Hall, D. E. Harrison, and D. Stammer Venice, 21-25.

Hanna, E., Cappelen, J., Fettweis, X., Huybrechts, P., Luckman, A., and Ribergaard, M. H. (2009). Hydrologic response of the Greenland ice sheet: the role of oceanographic warming. Hydrol. Process. 23, 7-30. doi: 10.1002/hyp.7090

Hanna, E., Cropper, T. E., Hall, R. J., and Cappelen, J. (2016). Greenland blocking index 1851-2015: a regional climate change signal. Int. J. Climatol. 36, 48474861. doi: $10.1002 /$ joc. 4673

Hanna, E., FNavarro, J., Pattyn, F., Domingues, C. M., Fettweis, X., Ivins, R. E., et al. (2013). Ice sheet mass balance and climate change. Nature 498, 51-59. doi: $10.1038 /$ nature 12238

Hanna, E., Hall, R. J., Cropper, T. E., Ballinger, T. J., Wake, L., Mote, T., et al. (2018). Greenland blocking index daily series 1851-2015: analysis of changes in extremes and links with North Atlantic and UK climate variability and change. Int. J. Climatol. 38, 3546-3564. doi: 10.1002/joc.5516

Heimbach, P., Straneo, F., Sergienko, O., and Hamilton, G. (2014). International Workshop on Understanding the Responses of Greenland's Marine-Terminating Glaciers to Oceanic and Atmospheric Forcing: Challenges to Improving Observations, Process Understanding and Modeling. US CLIVAR Report No 2014-1. Washington, DC: US CLIVAR Project Office, 36.

Henry, L. G., McManus, J. F., Curry, W. B., Roberts, N. L., Piotrowski, A. M., and Keigwin, L. D. (2016). North Atlantic ocean circulation and abrupt climate change during the last glaciation. Science 353, 470-474. doi: 10.1126/science. aaf5529 
Holland, D. M., Thomas, R. H., de Young, B., Ribergaard, M. H., and Lyberth, B. (2008). Acceleration of Jakobshavn Isbræ triggered by warm subsurface ocean waters. Nat. Geosci. 1:659. doi: 10.1038/ngeo316

Hopwood, M. J., Carroll, D., Browning, T. J., Meire, L., Mortensen, J., Krisch, S., et al. (2018). Non-linear response of summertime marine productivity to increased meltwater discharge around Greenland. Nat. Commun. 9:3256. doi: 10.1038/s41467-018-05488-8

Howat, I., Negrete, A., and Smith, B. (2017). MEaSUREs Greenland Ice Mapping Project (GIMP) Digital Elevation Model from GeoEye and WorldView Imagery, Version 1. Boulder, CO: NASA National Snow and Ice Data Center Distributed Active Archive Center.

Inall, M. E., Murray, T., Cottier, F. R., Scharrer, K., Boyd, T. J., Heywood, K. J., et al. (2014). Oceanic heat delivery via Kangerdlugssuaq Fjord to the southeast Greenland ice sheet. J. Geophys. Res. Oceans 119, 631-645. doi: 10.1002/ 2013JC009295

Jackson, R. H., Shroyer, E. L., Nash, J. D., Sutherland, D. A., Carroll, D., Fried, M. J., et al. (2017). Near-glacier surveying of a subglacial discharge plume: implications for plume parameterizations. Geophys. Res. Lett. 44, 6886-6894. doi: 10.1002/2017GL073602

Jackson, R. H., and Straneo, F. (2016). Heat, salt, and freshwater budgets for a glacial fjord in Greenland. J. Phys. Oceanogr. 46, 2735-2768. doi: 10.1175/JPOD-15-0134.1

Jackson, R. H., Straneo, F., and Sutherland, D. A. (2014). Externally forced fluctuations in ocean temperature at Greenland glaciers in non- summer months. Nat. Geosci. 7, 503-508. doi: 10.1038/ngeo2186

James, T. D., Murray, T., Selmes, N., Scharrer, K., and O’Leary, M. (2014). Buoyant flexure and basal crevassing in dynamic mass loss at Helheim Glacier. Nat. Geosci. 7, 593-596. doi: 10.1038/ngeo2204

Jenkins, A. (2011). Convection-driven melting near the grounding lines of ice shelves and tidewater glaciers. J. Phys. Oceanogr. 41, 2279-2294. doi: 10.1175/ JPO-D-11-03.1

Joughin, I., Howat, I., Smith, B., and Scambos, T. (2011). Updated 2018. MEaSUREs Greenland Ice Velocity: Selected Glacier Site Velocity Maps from InSAR, Version 1. Boulder, CO: NASA National Snow and Ice Data Center Distributed Active Archive Center.

Joughin, I., Moon, T., Joughin, J., and Black, T. (2017). MEaSUREs Annual Greenland Outlet Glacier Terminus Positions from SAR Mosaics, Version 1. Boulder, CO: NASA National Snow and Ice Data Center Distributed Active Archive Center. doi: 10.5067/OC7B04ZM9G6Q

Juul-Pedersen, T., Arendt, K. E., Mortensen, J., Blicher, M. E., Sogaard, D. H., and Rysgaard, S. (2015). Seasonal and interannual phytoplankton production in a sub-Arctic tidewater outlet glacier fjord, SW Greenland. Mar. Ecol. Prog. Ser. 524, 27-38. doi: 10.3354/meps11174

Kanna, N., Sugiyama, S., Ohashi, Y., Sakakibara, D., Fukamachi, Y., and Nomura, D. (2018). Upwelling of macronutrients and dissolved inorganic carbon by a subglacial freshwater driven plume in Bowdoin Fjord, Northwestern Greenland. J. Geophys. Res. Biogeosci. 123, 1666-1682. doi: 10. 1029/2017JG004248

Kimura, S., Holland, P. R., Jenkins, A., and Piggott, M. (2014). The effect of meltwater plumes on the melting of a vertical glacier face. J. Phys. Oceanogr. 44, 3099-3117. doi: 10.1175/JPO-D-13-0219.1

Kjeldsen, K. K., Weinrebe, R. W., Bendtsen, J., Bjørk, A. A., and Kjær, K. H. (2017). Multibeam bathymetry and CTD measurements in two fjord systems in southeastern Greenland. Earth Syst. Sci. Data 9, 589-600. doi: 10.5194/essd9-589-2017

Korsgaard, N. J., Nuth, C., Khan, S. A., Kjeldsen, K. K., Bjørk, A. A., Schomacker, A., et al. (2016). Digital elevation model and orthophotographs of Greenland based on aerial photographs from 1978-1987. Sci. Data 3:160032. doi: 10.1038/sdata. 2016.32

Krabill, W., Frederick, E., Manizade, S., Martin, C., Sonntag, J., Swift, R., et al. (1999). Rapid thinning of parts of the southern Greenland Ice Sheet. Science 283, 1522-1524. doi: 10.1126/science.283.5407.1522

Krabill, W., Hanna, E., Huybrechts, P., Abdalati, W., Cappelen, J., Csatho, B., et al. (2004). Greenland ice sheet: increased coastal thinning. Geophys. Res. Lett. 31, 1-4. doi: 10.1029/2004GL021533

Laidre, K. L., Born, E. W., Atkinson, S. N., Wiig, $\varnothing$, Andersen, L. W., Lunn, N. J., et al. (2018a). Range contraction and increasing isolation of a polar bear subpopulation in an era of sea-ice loss. Ecol. Evol. 8, 2062-2075. doi: 10.1002/ ece3.3809

Laidre, K. L., Stern, H., Born, E. W., Heagerty, P., Atkinson, S., Wiig, Ø, et al. (2018b). Changes in winter and spring resource selection by polar bears Ursus maritimus in Baffin Bay over two decades of sea-ice loss. Endanger. Species Res. 36, 1-14. doi: 10.3354/esr00886

Laidre, K. L., Heide-Jørgensen, M. P., Ermold, W., and Steele, M. (2010). Narwhals document continued warming of southern Baffin Bay. J. Geophys. Res. 115:C10. doi: 10.1029/2009JC005820

Laidre, K. L., Moon, T., Hauser, D. D. W., McGovern, R., Heide-Jørgensen, M. P., Dietz, R., et al. (2016). Use of glacial fronts by narwhals (Monodon monoceros) in West Greenland. Biol. Lett. 12:20160457. doi: 10.1098/rsbl.2016.0457

Langen, P. L., Fausto, R. S., Vandecrux, B., Mottram, R. H., and Box, J. E. (2017). Liquid water flow and retention on the greenland ice sheet in the regional climate model HIRHAM5: local and large-scale impacts. Front. Earth Sci. 4:110. doi: $10.3389 /$ feart.2016.00110

Langen, P. L., Mottram, R. H., Christensen, J. H., Boberg, F., Rodehacke, C. B., Stendel, M., et al. (2015). Quantifying energy and mass fluxes controlling Godthåbsfjord freshwater input in a 5-km simulation (1991-2012). J. Clim. 28, 3694-3713. doi: 10.1175/JCLI-D-14-00271.1

Leuschen, C. J., Gogineni, S. P., Rodriguez-Morales, F., Paden, J. D., and Allen, C. (2018). IceBridge MCoRDS L2 Ice Thickness, Version 1. Boulder, CO: NASA National Snow and Ice Data Center Distributed Active Archive Center, doi: 10.5067/GDQ0CUCVTE2Q

Levin, L. A., Bett, B. A., Gates, A. R., Heimbach, P., Howe, B., Janssen, F., et al. (2019). Global observational needs in the deep Ocean. Front. Mar. Sci. (in press).

Lindsay, R., Wensnahan, M., Schweiger, A., and Zhang, J. (2014). Evaluation of seven different atmospheric reanalysis products in the Arctic. J. Clim. 27, 2588-2606. doi: 10.1175/JCLI-D-13-00014.1

Lozier, M. S., Bacon, S., Bower, A. S., Cunningham, S. A., de Jong, M. F., de Steur, L., et al. (2017). Overturning in the subpolar north atlantic program: a new international ocean observing system. Bull. Am. Meteorol. Soc. 98, 737-752. doi: 10.1175/BAMS-D-16-0057.1

Lydersen, C., Assmy, P., Falk-Petersen, S., Kohler, J., Kovacs, K. M., Reigstad, M., et al. (2014). The importance of tidewater glaciers for marine mammals and seabirds in Svalbard, Norway. J. Mar. Syst. 129, 452-471. doi: 10.1016/j.jmarsys. 2013.09.006

Machguth, H., Thomsen, H. H., Weidick, A., Ahlstrøm, A. P., Abermann, J., Andersen, M. L., et al. (2016). Greenland surface mass-balance observations from the ice-sheet ablation area and local glaciers. J. Glaciol. 62, 861-887. doi: $10.1017 /$ jog.2016.75

Mankoff, K. D., Straneo, F., Cenedese, C., Das, S. B., Richards, C. G., and Singh, H. (2016). Structure and dynamics of a subglacial discharge plume in a Greenlandic fjord. J. Geophys. Res. Oceans 121, 8670-8688. doi: 10.1002/2016JC0 11764

Meire, L., Mortensen, J., Meire, P., Juul-Pedersen, T., Sejr, M. K., Rysgaard, S., et al. (2017). Marine-terminating glaciers sustain high productivity in Greenland fjords. Glob. Chang. Biol. 23, 5344-5357. doi: 10.1111/gcb.13801

Meire, L., Sogaard, D. H., Mortensen, J., Meysman, F. J. R., Soetaert, K., Arendt, K. E., et al. (2015). Glacial meltwater and primary production are drivers of strong CO2 uptake in fjord and coastal waters adjacent to the Greenland Ice Sheet. Biogeosciences 12, 2347-2363. doi: 10.5194/bgd-11-17925-2014

Mernild, S. H., Holland, D. M., Holland, D., Rosing-Asvid, A., Yde, J. C., Liston, G. E., et al. (2015). Freshwater flux and spatiotemporal simulated runoff variability into ilulissat icefjord, west greenland, linked to salinity and temperature observations near tidewater glacier margins obtained using instrumented ringed seals. J. Phys. Oceanogr. 45, 1426-1445. doi: 10.1175/JPOD-14-0217.1

Millan, R., Rignot, E., Mouginot, J., Wood, M., Bjørk, A. A., and Morlighem, M. (2018). Vulnerability of southeast greenland glaciers to warm atlantic water from operation icebridge and ocean melting greenland data. Geophys. Res. Lett. 45, 2688-2696. doi: 10.1002/2017GL07 6561

Moffat, C. (2014). Wind-driven modulation of warm water supply to a proglacial fjord, Jorge Montt Glacier, Patagonia. Geophys. Res. Lett. 41, 3943-3950. doi: 10.1002/2014GL060071 
Moon, T., Sutherland, D. A., Carroll, D., Felikson, D., Kehrl, L., and Straneo, F. (2017). Subsurface iceberg melt key to Greenland fjord freshwater budget. Nat. Geosci. 11, 49-54. doi: 10.1038/s41561-017-0018-z

Morlighem, M., Rignot, E., Seroussi, H., Larour, E., Dhia, H. B., and Aubry, D. (2011). A mass conservation approach for mapping glacier ice thickness. Geophys. Res. Lett. 38:L19503. doi: 10.1002/2017GL074954

Morlighem, M., Williams, C. N., Rignot, E., An, L., Arndt, J. E., Bamber, J. L., et al. (2017). BedMachine v3: complete bed topography and ocean bathymetry mapping of Greenland from multibeam echo sounding combined with mass conservation. Geophys. Res. Lett. 44, 11051-11061. doi: 10.1002/2017GL07 4954

Mortensen, J., Bendtsen, J., Lennert, K., and Rysgaard, S. (2014). Seasonal variability of the circulation system in a West Greenland tidewater outlet glacier fjord, Godthåbsfjord (64N). J. Geophys. Res. Earth Surf. 119, 2591-2603. doi: 10.1002/2014JF003267

Mortensen, J., Bendtsen, J., Motyka, R. J., Lennert, K., Truffer, M., Fahnestock, M., et al. (2013). On the seasonal freshwater stratification in the proximity of fastflowing tidewater outlet glaciers in a sub-Arctic sill fjord. J. Geophys. Res. Oceans 118, 1-14. doi: 10.1002/jgrc.20134

Mortensen, J., Rysgaard, S., Arendt, K. E., Juul-Pedersen, T., Søgaard, D. H., Bendtsen, J., et al. (2018). Local coastal water masses control heat levels in a west Greenland tidewater glacier fjord. J. Geophys. Research. Oceans 123, 8068-8083. doi: 10.1029/2018JC014549

Mottram, R., Simonsen, S. B., Høyer Svendsen, S., Barletta, V. R., Sandberg Sørensen, L., Nagler, T., et al. (2018). An integrated view of greenland ice sheet mass changes based on models and satellite observations. Preprints 2018:2018100337. doi: 10.20944/preprints201810.0337.v1

Mottram, R., Boberg, F., Langen, P., Yang, S., Rodehacke, C., Christensen, J. H., et al. (2017a). Surface mass balance of the greenland ice sheet in the regional climate model HIRHAM5: present state and future prospects. Low Temp. Sci. 75, 1-11. doi: 10.14943/lowtemsci

Mottram, R., Nielsen, K. P., Gleeson, E., and Yang, X. (2017b). Modelling glaciers in the HARMONIE-AROME NWP model. Adv. Sci. Res. 14, 323-334. doi: 10.5194/asr-14-323-2017

Motyka, R., Hunter, L., Echelmeyer, K., and Connor, C. (2003). Submarine melting at the terminus of a temperate tidewater glacier, LeConte Glacier, Alaska, U.S.A. Ann. Glaciol. 36, 57-65. doi: 10.3189/172756403781816374

Motyka, R. J., Truffer, M., Fahnestock, M. A., Mortensen, J., Rysgaard, S., and Howat, I. M. (2011). Submarine melting of the 1985 Jakobshavn Isbrae floating tongue and the triggering of the current retreat. J. Geophys. Res. 116:F01007. doi: 10.1029/2009JF001632

Murphy, D. L., and Cass, D. L. (2012). The international ice patrol: safeguarding life and property at sea. Coast guard journal of safety \& security at Sea. Proc. Mar. Safety Secur. Council 69, 13-16.

Murray, T., Scharrer, K., James, T. D., Dye, S. R., Hanna, E., Booth, A. D., et al. (2010). Ocean regulation hypothesis for glacier dynamics in southeast Greenland and implications for ice sheet mass changes. J. Geophys. Res. Earth Surf. 115:F03026. doi: 10.1029/2009JF001522

Murray, T., Scharrer, K., Selmes, N., Booth, A. D., James, T. D., Bevan, S. L., et al. (2015). Extensive Retreat of Greenland Tidewater Glaciers, 2000-2010. Arct. Antarct. Alpine Res. 47, 427-447. doi: 10.1657/AAAR0014-049

Myers, P. G., Donnelly, C., and Ribergaard, M. H. (2009). Structure and variability of the West Greenland current in summer derived from 6 repeat standard sections. Prog. Oceanogr. 80, 93-112. doi: 10.1016/j.pocean.2008. 12.003

National Academies of Sciences, Engineering, and Medicine (NASEM) (2016). Frontiers in. (Decadal) Climate Variability: Proceedings of a Workshop. Washington, DC: National Academies Press, doi: 10.17226/23552

Nettles, M., and Ekström, G. (2010). Glacial earthquakes in Greenland and Antarctica. Annu. Rev. Earth Planet. Sci. 38, 467-491. doi: 10.1126/science. aab0460

Noël, B., van de Berg, W. J., Machguth, H., Lhermitte, S., Howat, I. M., Fettweis, X., et al. (2016). A daily, $1 \mathrm{~km}$ resolution data set of downscaled Greenland ice sheet surface mass balance (1958-2015). Cryosphere 10, 2361-2377. doi: 10.5194/tc10-2361-2016

Noël, B., van de Berg, W. J., Wessem, V., Melchior, J., Van Meijgaard, E., van As, D., et al. (2018). Modelling the climate and surface mass balance of polar ice sheets using RACMO2 - Part 1: Greenland (1958-2016). Cryosphere 12, 811-831. doi: 10.5194/tc-12-811-2018

Oliver, H., Luo, H., Castelao, R. M., van Dijken, G. L., Mattingly, K. S., Rosen, J. J., et al. (2018). Exploring the potential impact of greenland meltwater on stratification, photosynthetically active radiation, and primary production in the labrador Sea. J. Geophys. Res. Oceans 123, 2570-2591. doi: 10.1002/ 2018JC013802

O’Neel, S., Hood, E., Bidlack, A. L., Fleming, S. W., Arimitsu, M. L., Arendt, A., et al. (2015). Icefield-to-ocean linkages across the northern pacific coastal temperate rainforest ecosystem. Bioscience 65, 499-512. doi: 10.1093/biosci/ biv027

Overeem, I., Hudson, B. D., Syvitski, J. P. M., Mikkelsen, A. B., Hasholt, B., van den Broeke, M. R., et al. (2017). Substantial export of suspended sediment to the global oceans from glacial erosion in Greenland. Nat. Geosci. 79, 859-863. doi: 10.1038/ngeo3046

Poli, P., Hersbach, H., Dee, D. P., Berrisford, P., Simmons, A. J., Vitart, F., et al. (2016). ERA-20C: an atmospheric reanalysis of the twentieth century. J. Clim. 29, 4083-4097. doi: 10.1175/JCLI-D-15-0556.1

Porter, C., Morin, P., Howat, I., Noh, M.-J., Bates, B., Peterman, K., et al. (2018). ArcticDEM Version 1.1. Available at: https://dataverse.harvard.edu/ dataset.xhtml?persistentId=doi: 10.7910/DVN/OHHUKH.

Rignot, E., Box, J. E., Burgess, E., and Hanna, E. (2008). Mass balance of the Greenland ice sheet from 1958 to 2007. Geophys. Res. Lett. 35:L12505. doi: 10.1029/2008GL035417

Rignot, E., Fenty, I., Xu, Y., Cai, C., Velicogna, I., Cofaigh, C. Ó, et al. (2016). Bathymetry data reveal glaciers vulnerable to ice-ocean interaction in Uummannaq and Vaigat glacial fjords, west Greenland. Geophys. Res. Lett. 43, 2667-2674. doi: 10.1002/2016GL067832

Rignot, E., and Mouginot, J. (2012). Ice flow in Greenland for the international polar year 2008-2009. Geophys. Res. Lett. 39:L11501. doi: 10.1029/2012GL051634

Rignot, E., Mouginot, J., and Scheuchl, B. (2011). Ice flow of the antarctic ice sheet. Science 333, 1427-1430. doi: 10.1126/science.1208336

Roemmich, D., Johnson, G. C., Riser, S., Davis, R., Gilson, J., Owens, W. B., et al. (2009). The argo program: observing the global ocean with profiling floats. Oceanography 22, 34-43. doi: 10.5670/oceanog.2009.36

Roquet, F., Boehme, L., Fedak, M., Block, B., Charrassin, J.-B., Costa, D., et al. (2017). Ocean observations using tagged animals. Oceanography 30, 139-139. doi: 10.5670 /oceanog. 2017.235

Rysgaard, S., and BBOS Committee (2017). The Baffin Bay Observing System. Available at: https://www.asp-net.orgsitesdefaultfileswebsite_filesBBOS_6

Rysgaard, S., Mortensen, J., Juul-Pedersen, T., Sørensen, L. L., Lennert, K., Søgaard, D. H., et al. (2012). High air-sea CO2 uptake rates in nearshore and shelf areas of Southern Greenland: temporal and spatial variability. Mar. Chem. 12, 26-33. doi: 10.1016/j.marchem.2011.11.002

Schoof, C., Davis, A. D., and Popa, T. V. (2017). Boundary layer models for calving marine outlet glaciers. Cryosphere 11, 2283-2303. doi: 10.5194/tc-11-2283-2017

Sciascia, R., Straneo, F., Cenedese, C., and Heimbach, P. (2013). Seasonal variability of submarine melt rate and circulation in an East Greenland fjord. J. Geophys. Res. Oceans 118, 2492-2506. doi: 10.1002/jgrc.20142

Seale, A., Christoffersen, P., Mugford, R. I., and O'Leary, M. (2011). Ocean forcing of the Greenland ice sheet: calving fronts and patterns of retreat identified by automatic satellite monitoring of eastern outlet glaciers. J. Geophys. Res. Earth Surf. 116. doi: 10.1029/2010JF001847

Shean, D. E., Alexandrov, O., Moratto, Z. M., Smith, B. E., Joughin, I. R., Porter, C., et al. (2016). An automated, open-source pipeline for mass production of digital elevation models (DEMs) from very-high-resolution commercial stereo satellite imagery. ISPRS J. Photogramm. Remote Sens. 116, 101-117. doi: 10.1016/j. isprsjprs.2016.03.012

Slater, D. A., Nienow, P. W., Cowton, T. R., Goldberg, D. N., and Sole, A. J. (2015). Effect of near-terminus subglacial hydrology on tidewater glacier submarine melt rates. Geophys. Res. Lett. 42, 2861-2868. doi: 10.1002/2014GL062494

Smith, L. C., Yang, K., Pitcher, L. H., Overstreet, B. T., Chu, V. W., Rennermalm, ÅK., et al. (2017). Direct measurements of meltwater runoff on the Greenland ice sheet surface. Proc. Natl. Acad. Sci. 114, E10622-E10631. doi: 10.1073/pnas. 1707743114 
Sørensen, L. S., Simonsen, S. B., Forsberg, R., Khvorostovsky, K., Meister, R., and Engdahl, M. E. (2018). 25 years of elevation changes of the Greenland Ice Sheet from ERS, Envisat, and CryoSat-2 radar altimetry. Earth Planet. Sci. Lett. 495, 234-241. doi: 10.1016/j.epsl.2018.05.015

Spall, M. A., Jackson, R. H., and Straneo, F. (2017). Katabatic wind-driven exchange in fjords. J. Geophys. Res. Oceans 122, 8246-8262. doi: 10.1002/2017JC013026

Stearns, L. A., and van der Veen, C. J. (2018). Friction at the bed does not control fast glacier flow. Science 361, 273-277. doi: 10.1126/science.aat2217

Steffen, K., and Box, J. E. (2001). Surface climatology of the Greenland ice sheet: greenland climate network 1995-1999. J. Geophys. Res. 106, 33951-33964. doi: 10.1029/2001JD900161

Straneo, F., and Cenedese, C. (2015). The dynamics of Greenland's glacial fjords and their role in climate. Annu. Rev. Mar. Sci. 7, 89-112. doi: 10.1146/annurevmarine-010213-135133

Straneo, F., and Heimbach, P. (2013). North Atlantic warming and the retreat of Greenland's outlet glaciers. Nature 504, 36-43. doi: 10.1038/nature12854

Straneo, F., Heimbach, P., Sergienko, O., Hamilton, G. S., Catania, G., Griffies, S., et al. (2013). Challenges to understanding the dynamic response of greenland's marine terminating glaciers to Oceanic and atmospheric forcing. Bull. Am. Meteorol. Soc. 94, 1131-1144. doi: 10.1175/BAMS-D-12-00100.1

Straneo, F., Moon, T., Sutherland, D., Catania, G., Heimbach, P., and Stearns, L. (2018). "Establishing a Greenland Ice Sheet Ocean Observing System (GrIOOS)," in Proceedings of the Report from the 2015 Workshop, San Francisco, CA.

Straneo, F., Sutherland, D. A., Holland, D., Gladish, C., Hamilton, G. S., Johnson, H. L., et al. (2012). Characteristics of ocean waters reaching Greenland's glaciers. Ann. Glaciol. 53, 202-210. doi: 10.3189/2012AoG60A059

Sugiyama, S., Sakakibara, D., Tsutaki, S., Maruyama, M., and Sawagaki, T. (2015). Glacier dynamics near the calving front of Bowdoin Glacier, northwestern Greenland. Glaciol. J. 61, 223-232. doi: 10.3189/2015JoG14J127

Sulak, D. J., Sutherland, D. A., Enderlin, E. M., Stearns, L. A., and Hamilton, G. S. (2017). Iceberg properties and distributions in three Greenlandic fjords using satellite imagery. Ann. Glaciol. 58, 92-106. doi: 10.1017/aog.2017.5

Sutherland, D. A., Straneo, F., Stenson, G. B., Davidson, F. J. M., Hammill, M. O., and Rosing-Asvid, A. (2013). Atlantic water variability on the SE Greenland continental shelf and its relationship to SST and bathymetry. J. Geophys. Res. Oceans 118, 847-855. doi: 10.1029/2012JC008354

Task Team for an Integrated Framework for Sustained Ocean Observing (2012). A Framework for Ocean Observing. Paris: UNESCO.

Thornalley, D. J., Oppo, D. W., Ortega, P., Robson, J. I., Brierley, C. M., Davis, R., et al. (2018). Anomalously weak Labrador Sea convection and Atlantic overturning during the past 150 years. Nature 556, 227-230. doi: 10 . 1038/s41586-018-0007-4

Treasure, A. M., Roquet, F., Ansorge, I. J., Bester, M. N., Boehme, L., Bornemann, H., et al. (2017). Marine mammals exploring the oceans pole to pole: a review of the MEOP consortium. Oceanography 30, 132-138. doi: 10.5670/oceanog.2017.234

van As, D., Fausto, R. S., and Promice Project Team. (2011). Programme for monitoring of the greenland ice sheet (PROMICE): first temperature and ablation records. Geol. Surv. Den. Green. Bull. 23, 73-76.

van As, D., Mikkelsen, A. B., Holtegaard, M. N., Box, J. E., Claesson Liljedahl, L., Lindbäck, K., et al. (2017). Hypsometric amplification and routing moderation of Greenland ice sheet meltwater release. Cryosphere 11, 1371-1386. doi: 10. 5194/tc-11-1371-2017

Van den Broeke, M. R., Enderlin, E. M., Howat, I. M., Kuipers Munneke, P., Noël, B. P., van de Berg, W. J., et al. (2016). On the recent contribution of the Greenland ice sheet to sea level change. Cryosphere 10, 1933-1946. doi: 10.5194/tc-10-1933-2016

Velicogna, I., Sutterley, T. C., and van den Broeke, M. R. (2014). Regional acceleration in ice mass loss from Greenland and Antarctica using GRACE time-variable gravity data. Geophys. Res. Lett. 41, 8130-8137. doi: 10.1002/ 2014GL061052

Vieli, A., and Nick, F. M. (2011). Understanding and modelling rapid dynamic changes of tidewater outlet glaciers: issues and implications. Surv. Geophys. 32, 437-458. doi: 10.1007/s10712-011-9132-4

WCRP Global Sea Level Budget Group (2018). Global sea-level budget 1993present. Earth Syst. Sci. Data 10, 1551-1590. doi: 10.5194/essd-10-1551-2018

Wilkinson, M. D., Dumontier, M., Aalbersberg, I. J., Appleton, G., Axton, M., Baak, A., et al. (2016). The FAIR Guiding Principles for scientific data management and stewardship. Sci. Data 3:160018. doi: 10.1038/sdata.2016.18

Wilson, N., Straneo, F., and Heimbach, P. (2017). Satellite-derived submarine melt rates and mass balance (2011-2015) for Greenland's largest remaining ice tongues. Cryosphere 11, 2773-2782. doi: 10.5194/tc-11-2773-2017

Wilton, D. J., Jowett, A., Hanna, E., Bigg, G. R., Van Den Broeke, M. R., Fettweis, X., et al. (2017). High resolution $(1 \mathrm{~km})$ positive degree-day modelling of Greenland ice sheet surface mass balance, 1870-2012 using reanalysis data. J. Glaciol. 63, 176-193. doi: 10.1017/jog.2016.133

Wood, M., Rignot, E., Fenty, I., Menemenlis, D., Millan, R., and Morlighem, M. (2018). Ocean-induced melt triggers glacier retreat in Northwest Greenland. Geophys. Res. Lett. 45, 8334-8342. doi: 10.1029/2018GL078024

Xu, Y., Rignot, E., Menemenlis, D., and Koppes, M. (2012). Numerical experiments on subaqueous melting of Greenland tidewater glaciers in response to ocean warming and enhanced subglacial discharge. Ann. Glaciol. 53, 229-234. doi: 10.3189/2012AoG60A139

Yang, Q., Dixon, T., Myers, P., Bonin, J., Chambers, D., van den Broeke, M. R., et al. (2016). Recent increases in Arctic freshwater flux affects Labrador Sea convection and Atlantic overturning circulation. Nat. Commun. 7:10525. doi: $10.1038 /$ ncomms 10525

Yashayaev, I., and Loder, J. W. (2017). Further intensification of deep convection in the Labrador Sea in 2016. Geophys. Res. Lett. 44, 1429-1438. doi: 10.1002/ 2016GL071668

Conflict of Interest Statement: The authors declare that the research was conducted in the absence of any commercial or financial relationships that could be construed as a potential conflict of interest.

Copyright () 2019 Straneo, Sutherland, Stearns, Catania, Heimbach, Moon, Cape, Laidre, Barber, Rysgaard, Mottram, Olsen, Hopwood and Meire. This is an openaccess article distributed under the terms of the Creative Commons Attribution License (CC BY). The use, distribution or reproduction in other forums is permitted, provided the original author(s) and the copyright owner(s) are credited and that the original publication in this journal is cited, in accordance with accepted academic practice. No use, distribution or reproduction is permitted which does not comply with these terms. 